School of Finance

University of St.Gallen

UNIFORM-PRICE AUCTIONS FOR SWISS GOVERNMENT BONDS: ORIGIN AND EVOLUTION

ANGelo RANALDo

ENZO RossI

WORKING PAPERS ON FinANCE No. 2016/09

SWISS INSTITUTE OF BANKING AND FINANCE (S/BF - HSG)

MARCH 2016 


\section{Uniform-price auctions for Swiss government bonds: Origin and evolution}

Angelo Ranaldo and Enzo Rossi

\section{SNB Economic Studies}

$10 / 2016$ 


\section{Legal Issues}

\section{DISCLAIMER}

Economic Studies represent the views of the author(s) and do not necessarily reflect those of the Swiss National Bank.

\section{COPYRIGHTC}

The Swiss National Bank (SNB) respects all third-party rights, in particular rights relating to works protected by copyright (information or data, wordings and depictions, to the extent that these are of an individual character).

SNB publications containing a reference to a copyright (C) Swiss National Bank/SNB, Zurich/year, or similar) may, under copyright law, only be used (reproduced, used via the internet, etc.) for non-commercial purposes and provided that the source is mentioned. Their use for commercial purposes is only permitted with the prior express consent of the SNB.

General information and data published without reference to a copyright may be used without mentioning the source. To the extent that the information and data clearly derive from outside sources, the users of such information and data are obliged to respect any existing copyrights and to obtain the right of use from the relevant outside source themselves.

\section{LIMITATION OF LIABILITY}

The SNB accepts no responsibility for any information it provides. Under no circumstances will it accept any liability for losses or damage which may result from the use of such information. This limitation of liability applies, in particular, to the topicality, accuracy, validity and availability of the information.

ISSN 1661-142X (printed version)

ISSN 1661-1438 (online version)

(C) 2016 by Swiss National Bank, Börsenstrasse 15,

P.O. Box, $\mathrm{CH}-8022$ Zurich 


\section{SNB Economic Studies}

$10 / 2016$

\section{Uniform-price auctions for Swiss government bonds: Origin and evolution ${ }^{+}$}

Angelo Ranaldo* and Enzo Rossi**

\footnotetext{
+ We would like to thank Peter Thomann, Gregor Valko, Daniel Wittwer, the rest of the Swiss Treasury team and an anonymous referee for helpful comments and discussions. The views expressed in this study are those of the authors and do not necessarily reflect those of the SNB.

* University of St Gallen; angelo.ranaldo@unisg.ch

** Swiss National Bank and University of Zurich. Swiss National Bank, P.O. Box, CH-8022 Zurich; enzo.rossi@snb.ch
} 


\title{
Contents
}

1. Introduction 3

2. Public sector finance 4

3. The Federal Treasury 5

4. Standard auctions 7

5. The Swiss uniform-price auction 10

$\begin{array}{ll}5.1 \text { From syndication to auction } & 10\end{array}$

5.2 Why did the Swiss authorities choose the uniform-price format? 11

5.2.1 Revenue 11

5.2.2 Pros and cons of auction formats according to internal discussions 13

5.2.3 Treasury auction literature 14

6. Auction set-up 15

$\begin{array}{ll}6.1 \text { Bidding requirements } & 15\end{array}$

$\begin{array}{ll}6.2 \text { Bidders } & 16\end{array}$

6.3 Pre-auction information 18

$\begin{array}{ll}\text { 6.3.1 Auction calendar } & 18\end{array}$

6.3.2 Announcement of auction size 19

$\begin{array}{ll}6.4 \text { Bidding process } & 21\end{array}$

6.4.1 Auction period 21

6.4.2 Electronic platform as of March $2001 \quad 22$

6.5 Cut-off price 22

6.6 Announcement of results 23

7. Conclusions 24

Annex I: Major changes $\quad 25$

Annex II: Swiss Confederation bonds issued by auction 29

$\begin{array}{ll}\text { References } & 38\end{array}$

\begin{abstract}
The Swiss Treasury has used the sealed-bid, uniform-price auction format for allocating government bonds since 1980. In this study, we examine the authorities' motivation for choosing the uniform-price auction. In addition, we describe how the institutional set-up evolved over time. It includes bidding requirements, class of bidders, pre-auction information, the bidding process, the determination of the cut-off price and the release of post-auction information. Finally, we provide the details of each of the 356 auctions that were held until and including 2014.
\end{abstract}

JEL Codes: D44; G12; G20

Keywords: Government bonds; Treasury auctions; uniform-price auction 


\section{Introduction}

Raising finance to cover a government's borrowing needs, while minimising the cost of debt service and taking account of risk, is a common goal for public debt management. Different issuing techniques are available to debt managers to finance deficits and refinance maturing debt. Before the 1980s, most countries typically placed a large share of their debt with domestic banks, either directly or through a bank syndicate arrangement. As the funding demands of governments increased in the early 1980s, many countries introduced auctions either to replace or to supplement the traditional placement of securities with banks. Auctions are now the most common issuing method for government securities in many countries.

The main reason for choosing to sell government securities by auction rather than by fixed-price public subscriptions is that the auction technique is market-oriented - the government does not know the bidders' valuations and therefore lets the market determine the yield. Auctions are also transparent - the sale of securities is announced in advance, bidders submit their bids, and allocation is purely by price. However, auctions also entail a potential risk to the government. There may be insufficient demand to cover the amount that it wishes to sell, or the price may be below the minimum deemed acceptable. Because of the inherent transparency of the auction, the market will become aware of this. In choosing and designing the features of the auction system for government securities, debt managers need to take account of risks and benefits, and consider ways in which to reduce uncertainty and maximise demand at an acceptable overall cost.

Raising funds for financing ongoing government activity and retiring debt becomes particularly challenging in times of financial turbulence and high budget deficits that worsen issuance conditions. This situation arose in the aftermath of the recent financial and economic crisis. At that time, the debt management strategy of most OECD countries was guided by the need to finance a large fiscal gap that was due to countercyclical fiscal measures and government intervention in support of an ailing banking sector.

In this study we discuss the reasons for adopting the auction format for selling Swiss Confederation notes and bonds (hereinafter referred to as 'bonds'). We describe its evolution and provide summary results of each auction. Two questions arise. First, why is the Swiss experience an interesting case to study? Secondly, why is it important to study the evolution of the auction format?

The Swiss case is particularly interesting for at least three reasons. First, Switzerland was in 1980 one of the first countries in the OECD to offer government medium and long-term securities (almost exclusively) by auction. Although auctions are generally believed to generate the best price possible for the issuer and establish a clear market price for the security, the decision to use an auction system is not straightforward as there are several auction formats. Switzerland opted for the sealed, multiple-bid, uniform-price technique, which it has applied since then without interruption. Secondly, the Swiss Treasury's experience with its auction procedure may be interesting because of the challenge posed by borrowing requirements that are relatively low and have even been declining in the recent crisis. Theoretically at least, this can affect market liquidity. Thirdly, although Switzerland has seen an ongoing decline in the public debt ratio in recent years, the country's experience 
is also marked by a long phase with accelerating budget deficits and debt that have led to changes in auction rules. Studying an auction format's evolution is important because exactly identifying changes to an auction's set-up is an initial step in empirically testing theoretical predictions that may advance our understanding of auctions. It might also contribute to auction experiment design.

The rest of this study is organised as follows. In Section 2 we illustrate Switzerland's financial situation since 1980, followed by a description of the Treasury's mandate. In Section 4 we discuss standard auction formats. Section 5 compares the two formats typically used by public treasurers. Section 6 sketches out the mechanism and bidding requirements for the auctions of Swiss central government bonds. Section 7 describes the major changes to the auction procedure that have been implemented either permanently or only temporarily. Section 8 offers a conclusion. In Annex I we present a chronological catalogue of major adaptations to the auction set-up and other institutional changes that might have had a bearing on bidders' behaviour and the auction outcome. To conclude, Annex II summarises the results of the 356 Swiss Confederation bonds issued by auctions from 1980-2014.

\section{Public sector finance}

Switzerland is traditionally a country with relatively low government spending, deficits and debt-to-GDP ratios. However, in the 1990s the public sector's financial situation worsened fast and strongly. More recently, public finances have improved noticeably, in contrast to many other OECD countries. ${ }^{1}$ As illustrated in Chart 1 , the Confederation's debt-to-GDP ratio is about $20 \%$, while overall public indebtedness amounts to less than $40 \%$ of GDP.

Chart 1: PubliC DEBT AS A FRACTION OF GDP

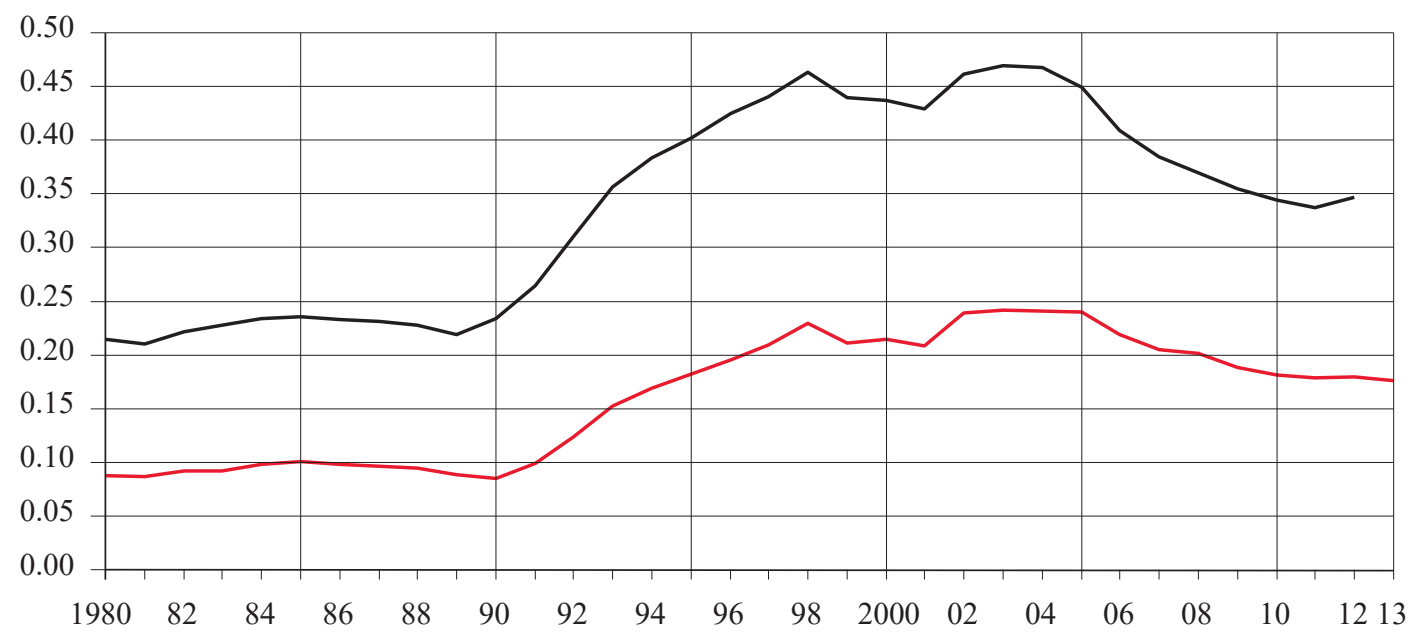

Note: The red line represents Confederation debt and the black line the debt of the public sector, comprising Confederation, cantonal and municipal debt, both as a fraction of GDP. Source: DataStream.

1 Cf. OECD (2013). 
Chart 2 shows the yearly average of the yield on ten-year Swiss Confederation bonds and Confederation debt as a percentage of GDP from 1980 to 2014 and 2013 respectively. After increasing to above $6 \%$ at the end of the $1980 \mathrm{~s}$, nominal yields have trended downwards. The lowest ten-year interest rate on a daily observation basis from $1980-2014$ is $0.307 \%$ and was recorded at the end of $2014 .^{2}$

Chart 2: TEN-YEAR YIELDS AND DEBT-TO-GDP RATIO

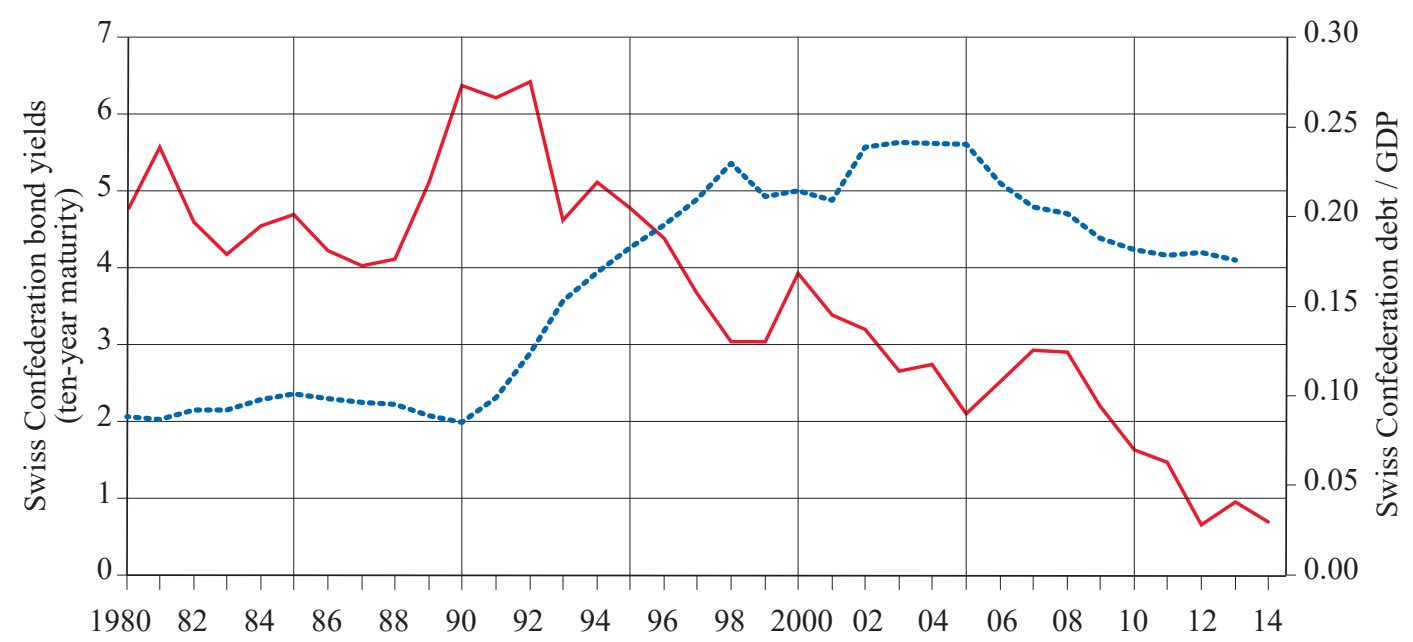

Note: The red line shows the nominal yield on ten-year Swiss Confederation bonds (yearly averages) and the blue dotted line Confederation debt as a fraction of GDP (right-hand scale). Source: DataStream.

Total market capitalisation of bonds on the Swiss market at the end of 2011 was about CHF 550 billion. ${ }^{3}$ This makes the Swiss franc market the eleventh-largest in an international comparison. The Confederation plays a dominant role in the bond market. In 2014, the outstanding volume of Swiss Confederation money market and capital market debt amounted to almost CHF 90 billion. ${ }^{4}$ Confederation debt securities represent the most liquid sector within the domestic bond market.

\section{The Federal Treasury}

The Swiss Federal Treasury, a unit within the Federal Finance Administration (FFA), is responsible for the permanent solvency of the federal government, its affiliated enterprises and establishments. It is in charge of raising funds on the money and capital markets and of the central procurement and management of foreign currency. It also administers all fixed-interest custody accounts of the federal administration,

2 Yields on government securities for maturities shorter than one year have been negative since August 2011. The yields on medium-term government securities also turned negative in 2011 (both the two-year yield and the four-year yield on 8.8.2011) and 2012 (the five-year yield on 30.5.2012) respectively. Yields for all maturities from 2 to 10 years turned negative in January 2015. Source: Bloomberg.

3 Cf. UBS (2013).

4 Cf. Federal Treasury (2015). 
processes special financing transactions, and administers and manages the significant holdings of the federal government. ${ }^{5}$

Sovereign securities can have a fixed or variable interest rate, be denominated in domestic or foreign currency, redeemable in nominal or price-indexed form, and carry different maturities. Because of trade-offs involved, choosing which type of bonds to select is not straightforward. Fixed interest rate instruments are highly liquid and easily tradable in secondary markets, notably for standardised maturities. At the same time they are subject to considerable interest rate risks for investors. Variable interest rate securities have reduced interest rate risk, but are more difficult to price and trade and are therefore less liquid. Short-term borrowing raises the variability of near-term interest expenses and complicates budget planning. By contrast, longer-term financing has a higher expected cost because of term premiums embedded in longer-term interest rates.

The main financing instruments of the Swiss Treasury are medium and longterm marketable bonds. Bond offerings in the auctions during our sample period (1980-2014) were exclusively in Swiss francs, nominal (with a denomination of CHF $1,000,5,000$ and 100,000) and with fixed interest rates. ${ }^{6}$ Interest rates (coupons) were payable at fixed annual intervals. ${ }^{7}$ The average coupon of the auctioned bonds was $3.58 \%$ and the average yield $3.25 \%$. The issue price was $102.97 \%$ on average. The lowest price fell as low as $88.50 \%$, while the highest price attained $168.50 \%{ }^{8}$ The size of funds raised in the auctions amounts to CHF 149.435 billion. ${ }^{9}$

The overall objective of the Swiss Treasury is to cover the central government's financing needs at minimum funding costs, while reducing interest and refinancing risks to an acceptable level. ${ }^{10}$ Several factors may help achieve this objective. ${ }^{11}$ They comprise an increase in the number of participants in the primary and secondary markets as well as a widening of the institutional base. Additional factors are an enforced professionalism in the price-making process, intensification of competition, institutionalisation, and improvement in information-sharing activities. Furthermore, in order to achieve the Treasury's objectives, it is important to have enhanced, sustained liquidity of outstanding issues by means of a policy geared towards transparency and regularity.

5 http://www.efv.admin.ch/e/efv/organisation/index.php

6 The Swiss Confederation has issued foreign currency debt on rare occasions in the past, as for instance on 1 August 1923, when it offered a $5 \%$ bond ending in 1926 and amounting to USD 20 million (Bischofberger 1997, fn. 14.). No price-indexed bonds have ever been offered by the Swiss Confederation.

7 Except for three convertible bonds issued between 2003 and 2004 and maturing between 2005 and 2007; two of them were zero-coupon bonds and one had a $0.25 \%$ coupon.

8 Cf. Table 2 in the Annex for details.

9 These figures do not include the Treasury's own tranches. Cf. section 6.3.2.

10 Cf. Federal Treasury (2015, p. 11).

11 Cf. Bernhard and Rossi (2000). 


\section{Standard auctions}

The academic literature on auctions has made many important contributions. Research has classified various auction formats, modelled bidding strategies, and ranked the results by various criteria such as seller revenue, allocative efficiency and bidder profits.

An important feature of an auction is its format. The auction format determines the payment of the winning bidder. On the one hand, securities can be awarded at prices that are progressively lowered until the entire issue is sold. But on the other hand, the auctioneer can arrange the bids in ascending order by their price and decide on a single price that places the total issue. Auctions can further be a private affair with sealed bids opened by the auctioneer, or they can be conducted in real time.

This two-by-two classification yields four primary auction formats. Two are called open-outcry auctions and the other two are referred to as sealed-bid auctions. In open formats, the potential sale price changes during the auction as the auctioneer announces the current winning bid to all bidders, for bidding occurs sequentially. ${ }^{12}$ These auctions are dynamic. They involve multiple rounds of price-and-demand adjustment, or continuous price changes, with a specified stopping rule. Dynamic auctions may be either ascending (increasing price) or descending (decreasing price). ${ }^{13}$

In sealed-bid auctions, prices are not called out by an auctioneer but are submitted privately and simultaneously by bidders without revealing them to others. ${ }^{14}$ Bidders might not even know the identity and number of participants. After the bidding has closed, the bids are opened and ranked according to price, from the highest to the lowest. These auctions are static. The bids are submitted only once, and the prices and allocations are immediately determined.

Another difference among auctions is related to the number of objects auctioned. If only one object is offered, the auction is called a single-item (or single-unit) auction. If several copies of the same object are offered, such as batches of Treasury securities, then the auction is called a multi-item (or multi-unit) auction. ${ }^{15}$

In the description of primary auction types we follow the academic terminology.

\section{English auction}

A popular open auction format is the English auction. Starting with a low first bid, the auctioneer solicits increasingly higher bids. In the case of a single item, the price is raised successively until only one bidder remains. The item is sold to the last and highest bidder for the amount bid. In a multi-unit auction, the process continues until arriving at a price at which the fixed amount supplied is just matched by demand. ${ }^{16}$ This auction type is sometimes called the oral or ascending-bid, open-outcry auction. It is commonly used in the art world and in web-based auctions. ${ }^{17}$

12 This means open auctions are sequential games.

13 Cf. Kwasnica and Sherstyuk (2013).

14 In the language of game theory, bids are simultaneous actions.

15 There are also auctions in which several objects with different characteristics are offered at the same time. Examples are auctions of regional communication licenses with licenses for different regions put up for sale simultaneously.

16 Cf. Feldman and Mehra (1993).

17 A closely related open-outcry, ascending auction is the Japanese or 'button' auction in which the price starts very low and each bidder presses a 'button'. The price increases continuously and bidders release the button and quit the auction. 


\section{Dutch auction}

Another popular open auction format for a single item is the Dutch auction. It is the converse of the English format. In a Dutch auction, also called a descending-price, open-outcry auction, the auctioneer calls out an initial high price and then lowers the bid successively until a bidder accepts the current bid. When multiple units are being auctioned, this process continues until arriving at a price whereby the fixed amount supplied is matched by total demand. The Dutch auction has been used for centuries for selling produce and fresh flowers. Both the English and the Dutch auctions are dynamic auctions: participants bid sequentially over time and (potentially) learn something about their opponents' bids.

\section{Single item: First-price, sealed-bid auction}

In a first-price, sealed-bid auction, bidding is again for a single unit, but takes place in private. Each bidder has the opportunity to submit a single bid independently. The highest bidder wins the good at the bid price. This mechanism is used in auctions of mineral rights on government-owned land and sometimes in the sales of artwork and real estate. ${ }^{18}$

\section{Single item: Second-price, sealed-bid auction}

In a second price, sealed-bid auction, each buyer of a single unit also submits a single private bid independently. The item is still awarded to the buyer with the highest bid. However, the price the winner pays is equal not to her own bid, but to the secondhighest bid for the object offered. For this reason, this procedure is known as a secondprice, sealed-bid auction. It is sometimes labelled a Vickrey auction. This auction is rare in practice. It has, for instance, been employed for stamp auctions by mail. ${ }^{19}$

\section{Multi-items: Discriminatory auction (DPA)}

In situations with multiple objects, bidders submit bids at multiple prices and vary the number of units bid at each price. Awards start with the highest price and continue until the amount offered is covered. Each successful bidder has to pay the bid price so that the cost of the total issue corresponds to the weighted average of the yields of all accepted bids. The auctioneer acts like a discriminating monopolist, charging different prices to different bidders, extracting the consumer surplus under the demand schedule. For this reason, this auction type is called a discriminatory auction (pay-as-bid, bid-price, multiple-price or multiple-yield auction).

\section{Multi-items: Uniform-price auction (UPA)}

As in discriminatory auctions, bidders submit bids at multiple prices and vary the number of units bid at each price. Awards are still made in order of descending prices. However, each successful bidder pays the same market clearing price. This uniform price is the lowest price that exhausts the auction supply (the lowest price at which

18 Cf. Klemperer (1999). The first-price, sealed-bid auction is strategically equivalent to the Dutch auction, because no information is learned during the auction and the bidding strategy is equivalent to deciding at what price to buy the auctioned object.

19 The second-price, sealed-bid auction is weakly equivalent to the English and the Japanese auction. The weakness arises from the information that bidders learn with open formats. 
bids are accepted). This auction type is thus called a uniform-price (or competitive) auction. There are three variants in the uniform-price format to set the price: (i) either at the highest losing bid (highest loser), (ii) at the lowest winning bid (lowest winner) or (iii) between the two. ${ }^{20}$

There is some confusion in the terminology. In the financial community, second-price or uniform-price auctions are referred to as Dutch auctions. A similar confusion arises around first-price or discriminatory auctions. In the financial community, this type of auction is referred to as an English auction except in the United Kingdom, where it is called an American auction. ${ }^{21}$

A key feature is the presence of asymmetric information, leading to an important distinction between independent private and common-value auctions. The value of the unit for sale is of a private nature to the bidder if he knows the exact value it has to him, and this value is not affected by information regarding the values of other bidders. Bidders' valuations are subjective decisions, independent of each other. Bidders are interested in the valuations of others only to the extent that this affects how high they have to bid.

If this is not the case, or if there is a possibility of resale, the unit for sale has a common value. Under this assumption - typically the situation in which bidders purchase an object for resale rather than for personal consumption - each bidder has the same value for the object. They do not know what the object will be worth, but they know that whoever gains the object will receive the same amount by selling it in the market. This value is not known to bidders with certainty at the time of the auction. Each bidder still has private information regarding the value of the good, but now it is only an estimate. Because each bidder has only an estimate of the true value, there is an interest in obtaining as much information as possible regarding the value estimates of other bidders. It is usually assumed that on average the bidders' estimates are correct. However, even though bidders' estimates are unbiased, some estimates will be high and others low.

Government securities auctions share a number of features in common with other auctions. They are usually considered as common-value auctions because the security's value is a common and unknown resale price and because of the existence of a post-auction secondary market. The usual argument is that primary dealers buy in the auction primarily to resell in the secondary market. Bidders ex-post place the same value on the object which would equal the secondary market price. Ex ante this value is unknown.

20 While the DPA can be correctly viewed as a multi-unit generalisation of the first price auction, the UPA only bears a superficial resemblance to the second-price auction of a single item (Ausubel and Cramton 2002; Ausubel 2008; Ausubel, Cramton, Pycia, Rostek and Weretka 2013). The correct multi-unit generalisation of the second-price auction is the multi-unit Vickrey auction. Cf. Ausubel (2008).

21 Cf. Feldman and Mehra (1993). Another auction format that is associated with a country is the Spanish auction, which is a hybrid of the UPA and the DPA. In it, winning bidders are charged the average winning bid for all bids above the average, while all winning bids below the average are fully paid. This auction has been employed since 1987 in Spain to sell Treasury securities. Cf. Álvarez and Mazón (2002) for theoretical analysis and Armantier and Lafhel (2009) for a (counterfactual) empirical assessment of this format on Canadian data. 
At the same time, Treasury auctions exhibit several unique characteristics. ${ }^{22}$ They are typically repeated at regular intervals with the set of bidders remaining mostly the same. Bidders in Treasury auctions cannot observe others' bids (sealed bids), unlike those participating in the more traditional auctions of single items such as antiques or art; this can partially be explained by the difficulty of getting all the bidders in the same room for open bidding. ${ }^{23}$ There may also be an active when-issued market in which participants can purchase identical goods before the auction for forward delivery after the auction. ${ }^{24}$ Active trading in the secondary market sets in after the auction. Furthermore, Treasury auction participants can be divided into non-competitive and competitive bidders.

\section{The Swiss uniform-price auction}

\subsection{From syndication to auction}

Switzerland was one of the first OECD countries to introduce auctions for government securities at the end of the 1970s, after years of negative experiences with syndicated fixed-price subscription offerings. ${ }^{25}$ In general, syndication facilitates a high initial volume of issue, with better placing certainty, reducing the execution risk relative to auctions. This may, in turn, lead to higher liquidity and lower borrowing costs. However, this selling method also has some potential downsides, including a more limited reach across potential buyers, less commitment of risk capital by primary dealers and higher intermediation costs. ${ }^{26}$

In the Swiss case, the syndicated fixed-price subscription offerings were in many respects unsatisfactory and cumbersome. In particular, offerings were either grossly underpriced and oversubscribed or they were overpriced, making it difficult for the Swiss Confederation to raise large amounts of money as needed. They were used as an opportunity to raise interest rates. ${ }^{27}$ Moreover, there was mounting political criticism that the Confederation would have to offer conditions for the participants in the fixed-price offerings that would have been too good. There were also comments about the banks enjoying too high a commission. These reasons prompted the Confederation, together with the Swiss National Bank (SNB), to examine new issuance

22 Cf. Bikhchandani and Huang (1993), Das and Sundaram (1997), Nandi (1997), and Daripa (2001).

23 However, modern technology could enable more openness in the bidding process (Reinhart 1992).

24 Strictly speaking, a 'when-issued' market applies only in the case of auctions when a new bond is launched. In contrast, with a tranche of an existing bond, pre-auction trading takes place on the secondary market and a 'when-issued' market as such is not required. Simon (1994) documents that in the US the absence of trading in the auctioned securities before auctions caused less aggressive bidding.

25 Until the end of the 1970s only five countries used auction techniques or certain features of them for the sale of marketable medium-term and long-term government papers: Germany and the Netherlands since 1967, the US since 1970, Japan since 1978 and the UK since 1979 (cf. OECD 1983, Table 22).

26 Cf. Blommestein, Guzzo, Holland and Mu (2010).

27 Cf. Schwartz (1980) and Boesiger (1982). 
techniques which led to the introduction of an auction mechanism for allocating Confederation securities. ${ }^{28}$

By the beginning of the 1990s, most OECD countries had introduced auctions. In spite of similarities, the Swiss experience with auctions for central government securities differs in some respects from other countries. First, the Federal deficit and maturing debt have almost exclusively been covered with auction sales of securities. ${ }^{29}$ By contrast, although auctions nowadays are the procedure most commonly used among the OECD countries, in the wake of the recent crisis many countries introduced changes in issuance procedures and techniques. They include distribution methods other than auctions, such as mini-tenders, syndication, Dutch direct-auction procedures, and private placements. ${ }^{30}$ Secondly, while preference has customarily been given to DPA over UPA, ${ }^{31}$ the Swiss Treasury has exclusively employed the sealed-bid, uniform-price auction format with the price set at the lowest winning bid. Since July 1979 it has been using this auction format for marketing short-term debt register claims (commercial papers) and from 1980 for notes and bonds. ${ }^{32}$ Both types of auctions are run by the SNB on behalf of the Treasury.

\subsection{Why did the Swiss authorities choose the uniform-price format?}

\subsubsection{Revenue}

Since the 1960s there has been an intense debate about the most appropriate auction procedure for Treasury securities. Unfortunately, auction theory does not provide clear results. This may (partially) be related to traditional auction theory, which does not capture many important facets of Treasury auctions. For instance, while the analysis is usually embedded in a single-unit framework, Treasury securities are divisible multiple units of homogeneous goods for which bidders may submit a whole schedule of bids (demand functions). ${ }^{33}$ Moreover, traditional analysis neglects the existence of close substitutes for auctioned securities and trading in the whenissued market as well as the fact that dealers often bid at auctions with sizable short positions in auctioned securities.

Friedman (1959a,b) recommended selling Treasury securities by regularly scheduled auctions rather than fixed-price offerings, because of the difficulty of setting the

28 Cf. SBG/UBS (1984, p. 19).

29 For special Treasury bills (rescriptions), the Swiss Treasury opted for private placements with banks at fixed yields, amounts and maturities. In the 1990s the Confederation also issued (nontradable) time deposits. Cf. Annex I for details.

30 Cf. OECD (2012).

31 Cf. Bröker (1993, Tables VI.3, VI.4) and Bartolini and Cottarelli (1994). According to a recent survey by Brenner, Galai and Sade (2009) that covers 48 countries, 50\% of respondents use DPA, only $19 \%$ UPA, while $19 \%$ use both methods, depending on the type of debt instruments. In the OECD, six countries that use auctions as their issuing procedure (potentially together with other methods) rely currently entirely on UPA for both short-term and long-term debt, while nine countries exclusively use DPA for this purpose (OECD 2013, Table 4.2).

32 This constancy contrasts with half of the 48-country sample mentioned above, in which the selling mechanism has changed over time.

33 A large body of literature has since amassed on multi-unit auctions with demand function bids, questioning the view that the uniform-price auction may be seen as a multi-unit extension of the second-price, sealed-bid format with its attractive attributes. Cf., for instance, Ausubel et al. (2013). 
yield at a level where investors would buy the full amount offered. He also argued that switching from DPA to UPA would reduce financing costs. While the Treasury would give up the consumer surplus it receives as a discriminating monopolist under DPA, UPA would more than offset this decline in revenue by increasing demand on three counts. First, there would be more aggressive bidding because the fear of the 'winner's curse' would be reduced. ${ }^{34}$ Secondly, because UPA is strategically simpler, it would reduce bid preparation costs and broaden participation in auctions. Thirdly, UPA would level the playing field by reducing the importance of the dealers' specialised knowledge, narrowing the scope for brokers to collude and corner markets. ${ }^{35}$

Friedman's arguments are illustrated in Chart 3 and Chart 4. Chart 3 shows the amount of money received at a discriminatory-price auction compared with a uniformprice auction. The amount of money received at DPA is represented by the area ABCD and at UPA by $\mathrm{A}^{\prime} \mathrm{BCD}$. Under a uniform-price format, several bidders pay less than they have indicated that they are prepared to pay for the securities. For a given demand curve, the amount of money received using a uniform-price auction is therefore less than that received under a discriminatory-price auction, as the issuer foregoes potential income. This loss in revenue corresponds to the triangle $\mathrm{ABA}^{\prime}$ in Chart 3.

This notwithstanding, an issuer may prefer a uniform-price format. The reason is that the demand curve is not fixed. As argued by Friedman (1959a,b), a uniformprice auction reduces uncertainty for the bidders and so may encourage them to bid more aggressively than under a discriminatory-price auction. This would shift the demand curve up and to the right. The increased aggressiveness of bidding could more than offset the revenue lost to the Treasury from awarding securities at the lowest accepted price to those who had bid above that price.

The element of uncertainty in a discriminatory-price auction arises from the bidder's fear that he may pay above the market price for the security. The cut-off price is the marginal price that the market is prepared to pay for the volume of securities sold, and it is likely that secondary market trading will commence at around this level. Anyone who has bid above this price may therefore immediately face a markto-market loss as the securities 'successfully' obtained at the auction could have a lower resale value than the price paid (this is the winner's curse).

Chart 4 illustrates a case where the demand curve is higher under the uniform-price auction. The area $\mathrm{A}^{\prime \prime} \mathrm{B}^{\prime} \mathrm{B}$ represents the revenue gained by shifting the demand curve out and to the right through the use of a uniform-price auction. If this is larger than $\mathrm{AA}^{\prime \prime} \mathrm{A}^{\prime}$ (the revenue lost by awarding securities at the cut-off price rather than at bid prices), then a uniform-price auction results in higher revenue for the seller.

34 In common-value auctions, private information on the common valuation gives rise to the problem of the 'winner's curse'. This has its basis in differences between unconditional and conditional expectations. Winning bidders are those with the highest ex ante estimates. Even if each bidder obtains an unbiased estimate of an auctioned object before bid submission, winning conveys bad news to bidders because it means that all other bidders estimate the object's value lower. The winner's curse was originally studied by Wilson (1977) in a single-unit auction context. Ausubel (2004) has shown that in multi-unit auctions, the winner's curse might be potentially even more pronounced than in single-unit auctions. The more a bidder wins, the worse off he is. Ausubel calls it the 'champion's plague'.

35 Friedman (1991) reiterated this point against the background of attempts at cornering the US government securities market. 
Chart 3: UNIFORM-PRICE AUCTION VS. DISCRIMINATORY-PRICE AUCTION

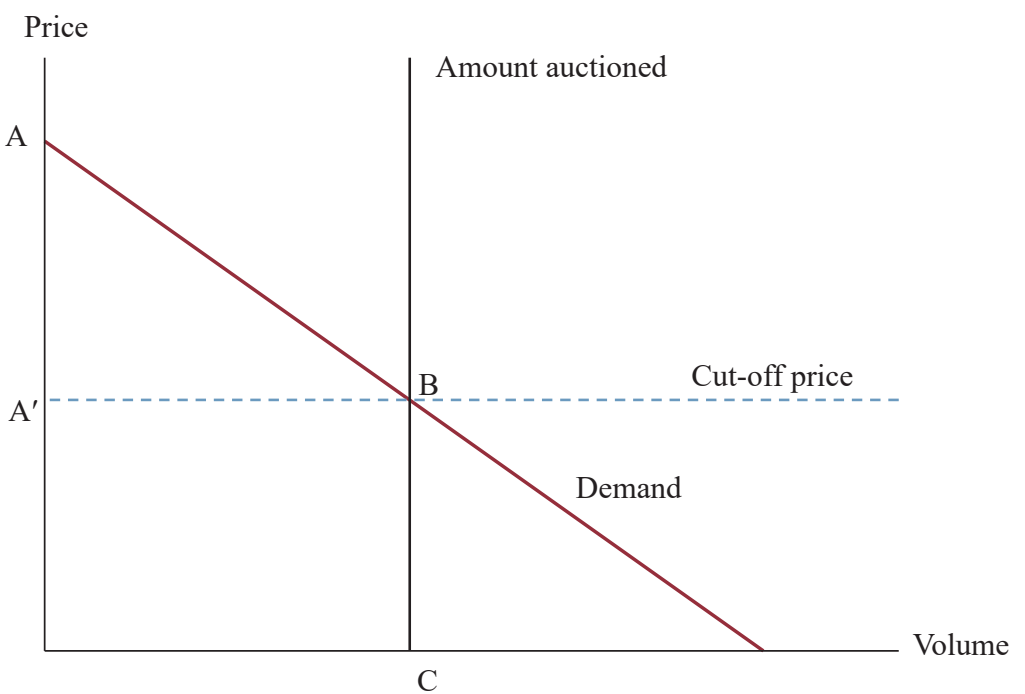

Chart 4: EFFECT OF A DEMAND SHIFT

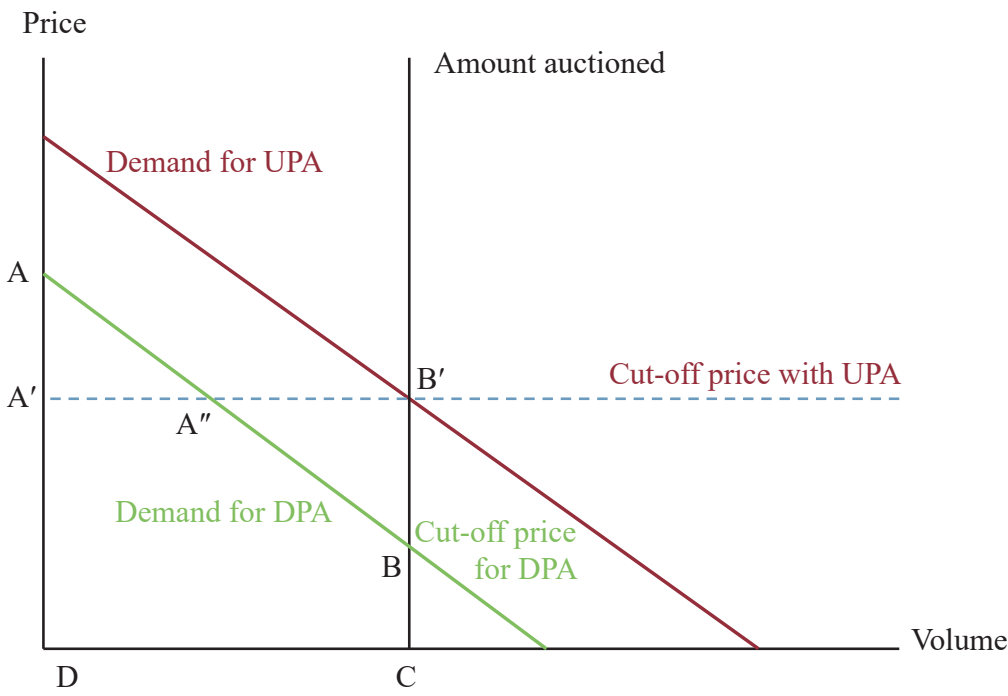

\subsubsection{Pros and cons of auction formats according to internal discussions} According to internal documents of the FFA, a number of pros and cons of UPA and DPA had been considered prior to the introduction of the auction mechanism. ${ }^{36}$

\section{i) Uniform-price auction}

Advantages associated with UPA were seen to be i) equality of treatment (since everybody pays the same price) and ii) the proximity of the auction price to the (secondary) market price. ${ }^{37}$ The most serious disadvantage was reckoned to be the

36 Eidgenössische Finanzverwaltung (1977).

37 One argument was probably also the relative simplicity of UPA in terms of computing the cut-off price from a numerous quantity of (phone) bids. The Joint Report on the Government Securities Market (1992, p. B-21) also emphasised that awards would make the auction demand curve coincide with the secondary market demand curve. Ausubel and Cramton (2002) call this identity 'the uniform-price auction fallacy'. 
possibility of stagging. Stagging was a typical feature in fixed-price offerings that led to distorted demand, resulting in oversubscription of an issue. However, this was not because demand was in effect significantly above supply, but to avoid rationing. Similarly, although this involved the bid price and not the size, it was argued that excessive prices would be offered in the UPA to increase the probability of winning. Expecting such behaviour could induce participants to submit several smaller bids at shaded prices. The highest bids would then be taken into account for sure, while the lower price bids would ensure that the final price would not be too high. As a result, the uniform price would be determined at random to some extent. ${ }^{38}$ Limiting the number of bids to one per bidder would eliminate the possibility of stagging, for nobody would risk offering an excessive price if similar behaviour by all other bidders could lead to an excessive final price.

\section{ii) $D P A$}

In a DPA, it was argued that price bids would be much nearer to the effective price because stagging would be costly for bidders. Bidders would submit high bids if they effectively had funds to invest. For them it would be of secondary importance if their purchased securities were traded at prices lower than their bid price. Speculative bidders would submit relatively low bids, trusting that the market price would end up higher. Unattractive features of DPA were believed to be the possibility of non-serious bids and the difficulties that bidding would entail for less experienced participants.

\subsubsection{Treasury auction literature}

Various theoretical models and numerous empirical analyses have not produced an unambiguous conclusion about the most appropriate auction mechanism for selling Treasury securities. In the theoretical analyses of McAfee and McMillan (1987), Milgrom (1989), Bikhchandani and Huang (1989), Reinhart (1992), Chari and Weber (1992) and Damianov and Becker (2010), UPA does better than DPA. By contrast, Milgrom (1987), Back and Zender (1993), Binmore and Swierzbinski (2000) and Nyborg and Strebulaev (2004) claim that UPA performs worse than DPA. Other studies, for instance Daripa (2001), conclude that revenue from DPA and UPA is hardly different. Moreover, Wang and Zender (2002) and Ausubel and Cramton (2002) suggest that a theoretical ranking of auction formats with respect to the revenue raised by the Treasury may be impossible in general. The authors conclude that the superiority of an auction format may only be determined empirically on a case-by-case basis.

Unfortunately, nor does empirical evidence prove conclusively which type creates more revenue..$^{39}$ In the only study of Swiss Treasury bond auctions of which we are aware, Heller and Lengwiler (2001) developed a method for generating counterfactual data on Swiss DPA using the effective data on reopenings in the Treasury's UPA

38 Interestingly, this discussion touched upon an issue that was later formalised and made popular under the title of bid shading or demand reduction that could lead to inefficiencies and reduced revenue. Ausubel and Cramton (2002) present a general theory of demand reduction and inefficiency in multi-unit auctions. Cf. also Ausubel et al. (2013).

39 There is also a sizeable, expanding body of experimental research on auctions that compares results under different formats. Cf. Kwasnica and Sherstyuk (2013) for a survey. 
(cf. 6.3.2) between October 1993 and June 2000..$^{40}$ They found that UPA reduces the government's financing costs by more than half a percentage point, vindicating the Swiss Treasury's choice. Others, such as Nyborg and Sundaresan (1996), Malvey, Archibald and Flynn (1995), Malvey and Archibald (1998), Keloharju, Nyborg and Rydqvist (2005), Armantier and Sbaï (2006) and Goldreich (2007), report generally favourable results for UPA from the Treasury's perspective in different countries. Other empirical studies report more favourable results for DPA of government securities, for instance Simon (1994), Hortaçsu (2002), and Armantier and Lafhel (2009).

\section{Auction set-up}

In this section, we describe the institutional set-up of the auction and its most important changes through time, comprising bidding requirements, the release of pre-auction information, the bidding process, the determination of the cut-off price, and the release of post-auction information.

\subsection{Bidding requirements}

Bidders in sovereign debt auctions typically fall into one of three categories: Primary dealers, dealer clients (indirect bidders), and direct bidders. In most OECD countries, primary dealers constitute the major bidder class. ${ }^{41}$ In some countries, participation in government securities auctions is limited to the primary dealers. Primary dealers may provide significant services to issuers by supplying information on the likely state of demand in advance of the issue, ensuring that the conditions for achieving the Treasury's ultimate target are met, and helping to market the security. Several countries also allow direct bidders to bid in Treasury auctions.

By contrast, the Swiss Treasury never installed a formal primary dealer system. Instead it relies informally on banks and institutional investors for creating a market for government bonds without granting them the rights or obligations of market-makers and formal compensation. ${ }^{42}$ Despite the absence of any sort of primary dealer system, the introduction of auction offerings was an instant success in Switzerland, even though the change to the auction mechanism seems to have met only weak acceptance from banks and was even the target of open criticism by others (Boesiger, 1982, p. 45, and Fortunato and Megevand, 1988, p. 36). ${ }^{43}$ Over the whole sample, the

40 Wasserfallen and Wydler (1988) examined the pricing of newly issued bonds, including Confederation bonds, on the Swiss capital market in comparison with seasoned bonds from 1980-1982.

41 Systems equivalent to primary dealers are recognised dealers, authorised dealers, and a consortium of institutional investors who function similarly to primary dealers. Other countries outside the OECD area have also set up primary dealers to promote bond markets. Arnone and Iden (2003) show the diffusion of the primary dealership system worldwide.

42 Bernhard and Rossi (2000) discuss the reasons against a formal, primary dealers system in Switzerland.

43 The immediate success is, for instance, in sharp contrast to the US experience where Treasury efforts to introduce bond auctions in the mid-1930s and again in the early 1960s had failed. The US Treasury had auctioned long-term bonds in 1935, but abandoned the auction method after five issues. It resumed the auction method in combination with the fixed-price format in 1963, but abandoned it after two issues. Only in the 1970s did the US Treasury replace fixed-price 
ratios of aggregate bids to awarded volumes (cover ratios) average 1.79 and range from 1.0 to 8.63. Only two announced auctions were cancelled.

The choice of auction format may be linked to the existence of a primary dealer system. Kroszner (1998) argues that some reform choices adopted in the 1980s and 1990 s, such as the use of the DPA rather than a UPA, appear to have been designed to enhance the relative value of the information that primary dealers have in these markets. Primary dealers would prefer to have the government use the DPA technique, and governments appear to have obliged. The renouncement of a formal primary dealer arrangement in Switzerland and the choice of UPA seems to be consistent with Kroszner's (1998) interpretation of preferences given to DPA in order to please primary dealers.

Similarly, Brenner, Galai and Sade (2009) document that market-oriented economies tend to rely on UPA while less market-oriented economies tend to prefer DPA. Their conjecture is that economies with less developed financial markets choose DPA because they are dependent on intermediaries to sell their issues. Intermediaries may prefer DPA because this auction format does not result in one known equal price to all bidders, which helps them realise a higher price in the secondary market.

\subsection{Bidders}

Consistent with the lack of an official primary dealer system, Swiss government bond auctions are open to widespread participation. Until the end of the 1990s, the only formal requirement for bidders was to have the status of a domestic bank. ${ }^{44}$ Since then, securities dealers and - under certain conditions - banks domiciled abroad have also been allowed to bid. Bidders in Swiss government bonds can be assigned to three classes: banks bidding for their own purposes, banks bidding for their clients (indirect bidders), and direct bidders. All bids from private persons and non-bank institutional investors have been collected by banks and forwarded to the SNB. ${ }^{45}$ The lack of primary dealers leads to equal treatment of bidders, at least in principle. In fact, bidders can be distinguished according to whether they submit competitive or non-competitive bids.

Competitive bidders are allowed to submit as many price-quantity bids as they wish, indicating the maximum price they are willing to pay (the minimum yield they are willing to accept) for a specified quantity of securities whereby increments are refined to five basis points. All successful competitive bidders pay the same price, computed from the lowest price at which competitive bids have been accepted (the highest accepted yield). There is no maximum either in terms of limit on the total number of bids that can be made by any one bidder or in terms of awards. ${ }^{46}$ However,

subscription offerings of notes and bonds after intermittently bad experiences with regular auctions (cf. Garbade 2004). By contrast, the US Treasury has been selling Treasury bills at auction ever since they were introduced in 1929 (cf. Garbade 2008).

44 The SNB is not authorised to bid for Confederation securities. According to the Swiss National Bank law, the SNB may not grant the Confederation loans or overdraft facilities; nor shall it be permitted to buy government bonds from new issues (art. 11 para. 2).

45 More recently, major non-bank investors were given the opportunity to bid directly at an auction.

46 This is in contrast to the US, for instance, where limits to the share of auction a bidder can acquire $(35 \%)$ are imposed. Such limits may play an important role in avoiding or reducing the 
competitive bidders do not know the exact amount of securities auctioned to them (if any). If they bid too cautiously, they risk getting nothing. ${ }^{47}$ Direct bidding on a competitive level has been very limited.

The uncertainty that a buyer might bid a price that is too low and not obtain the securities desired does not apply to non-competitive bidders. While direct competitive bidding has hardly materialised, direct non-competitive bidding can be observed among retail investors. Non-competitive bidders specify only the quantity of securities they agree to buy at whatever price is paid by successful competitive bidders, in the certainty that their demand will be entirely accommodated. A non-competitive auction is always conducted in association with the competitive auction. Non-competitive bidding is a means of encouraging the participation of retail and other small investors, who may not have current market information. Non-competitive bids are facilitated by a small, minimum denomination of CHF $1,000.48$

Everybody, including wholesale bidders, is entitled to submit (indirectly) non-competitive bids to be awarded in full. However, to emphasise the retail focus and to prevent financial institutions from making much use of the facility, an upper limit is set to the amount that individual non-competitive bidders can obtain. At the beginning, this limit was CHF 20,000 and it was raised to CHF 100,000 in March 1986. The motivation for this was to raise the popularity of government securities among private investors. ${ }^{49}$

In May 1992, the limit was suspended. Offers without indication of price would be invoiced at the cut-off price. This practice would be pursued for the following six auctions. The removal of the limit to non-competitive participants led to a dramatic increase in subscriptions without quotation, attaining a maximum of CHF 678.1 million in the November auction. The high, non-competitive demand does not seem to have been the result of a particularly strong demand from small investors, but rather of the intention by the banks to obtain a larger share in order to issue options on issue. ${ }^{50}$

Questions arose from the fact that numerous subscriptions without price offer hardly contribute to price formation. First, how would the Treasury fix the price if non-competitive bids had only marginally been lower than the announced maximum? ${ }^{51}$ Secondly, what would it do if non-competitive bids exceeded the announced maximum size on offer (which had been set at CHF 1 billion)? Would it award the full non-competitive bid amount, thus overriding the announced size limitation? How would it proceed to allocate any competitive bids? In order to prevent such outcomes

risk of occurrence of a squeeze, which is likely to damage the credibility of debt markets and make investors more reluctant to invest in government securities.

47 If a bidder is risk-averse, she will care very much about the risk of losing the object. In turn, she will be willing to pay more to avoid making a losing bid. The attitude towards risk is crucial for the aggressiveness in bidding.

48 Cf. Thomann (2002, p. 229).

49 Cf. Neue Zürcher Zeitung (1986).

50 Cf. Der Bund (1992).

51 An extreme example may serve to illustrate this. Assume that the auction size had been announced to be CHF 1 billion. Assume further that each of 9999 non-competitive bidders submitted a bid of CHF 100,000 and only one bidder bid competitively for an amount of CHF 100,000 . In this case the Treasury would have to fix the auction price based on the price offer of only one bidder which may be far away from the market view. 
in the future, the Treasury reinstalled the CHF 100,000 limit to non-competitive bids in the December 1992 auction.

\subsection{Pre-auction information}

To increase transparency and predictability, and to make it easier for market participants to plan ahead, debt managers usually announce an issuance calendar well in advance of the actual auctions. The calendars often include the size of the programme, the auction dates and the maturity ranges to be issued. In addition, a more detailed auction calendar may be issued at shorter intervals with details of the bonds to be offered. The scope for opportunistic issues, by taking advantage of temporary favourable market conditions, greatly diminishes. ${ }^{52}$

However, trade-offs between certainty and flexibility arise. On the one hand, the risk of a pre-determined issuance calendar is that it may commit the Treasury to offerings at a time when markets are unsettled. A related risk is that the Treasury may be committed to issuing a particular bond type or maturity when demand is low. As a result, the chance of auction failures increases. Another benefit that arises from deviating from preannouncements of auction size is that choosing actual supply conditional on demand can limit bidders' ability to influence the Treasury's choice of the cut-off price. This may work against collusion. ${ }^{53}$ For these reasons, a Treasury may prefer some discretion in its issuing policy. On the other hand, the more uncertain the borrowing policy, the more difficult it is for institutional investors to structure their investment portfolios. Furthermore, repeated deviations from announcements may be interpreted as the Treasury reneging on its promise to enhance the liquidity of the outstanding securities and increase the liquidity premium. ${ }^{54}$

\subsubsection{Auction calendar}

This trade-off notwithstanding, since April 1992 the Swiss Treasury has been committed to a yearly issuance programme that specifies how much it proposes to borrow in the following year - gross and net volumes - and states the auction dates that have been fixed (the closing date for subscription and, in the first issues of the calendar, also the payment date). However, the calendar does not predetermine the size of individual issues, nor does it state in advance the coupon and maturity.

The introduction of the calendar coincided with a strong expansion of the federal deficit and a tight financial position of the Federal Railway and Swiss Post (Chart 1). In order to avoid load peaks, the borrowing frequency was increased. ${ }^{55}$ Starting with the first calendar, the Treasury would announce one bond offering every fourth Thursday of the month, except for December. From 1995 onwards, the plan was to reduce the bond supply to bimonthly auctions. Since 2000 the announcement has

52 Cf. Wolswijk and de Haan (2005. This calls for continuity and regularity in the conduct of auctions throughout the year and not just when market opportunities arise.

53 Cf. Heller and Lengwiler (2001).

54 Piga (1998), for instance, models a time-inconsistency bias to issue illiquid bonds. Given the lack of flexibility that a calendar brings about, the optimal institutional design is shown to be an independent agency for debt management. Kroszner (1998) and Anderson (2006) discuss benefits and costs of independence in debt management.

55 From 1980 to 1991 the number of auctions in a year varied from two to seven. 
been again for monthly issuance. In the calendar for 2010 an innovation in terms of optional dates for the auctions was introduced.

As an example, the issue calendar for Confederation bonds in 2014, released on 3 December 2013 by the SNB and the FFA, offered information about scheduled issues for every month except for August. Notification is given in each individual case as to whether the optional dates in April, October and November will be used or not. The total volume of gross bond issuance in the Swiss capital market in 2014 was expected to amount to CHF 6.0 billion. The volume of bonds outstanding would be reduced by CHF 0.3 billion. The closing date for subscription was announced to be the second Wednesday of the month, with an indication of auction days. Finally, the press release stated that the payment date would be announced the day before the auction.

Apart from the broad guidelines provided by the calendar at year-end, the Treasury does not issue a detailed calendar during the year. In order to allow market participants to prepare for the auction, the Treasury established a period of notice for the details of an auction, ${ }^{56}$ comprising the coupon, the maturity and the intended borrowing size. Over time, the information about the amount to be borrowed became increasingly imprecise. Three phases can be distinguished.

\subsubsection{Announcement of auction size}

\section{i) From 1980 to October 1991: announcement of a range}

From 1980 to October 1991, the practice was to give the market a reasonable degree of certainty about the volume to be auctioned, while retaining some flexibility. To this end, the Treasury announced a range for the amount to be supplied. The average of those announcements was CHF 240.6 million, with a minimum of CHF 150.0 million and a maximum of CHF 300.0 million. In the March 1981 auction, the Treasury announced that it would reserve the right to reduce the size of the issue if it was not content with the outcome. The likely intention was to increase the bids of those wanting government securities by all means. ${ }^{57}$ In August 1991 (auction no. 53 in Table 2), the announced auction was cancelled even after preparations for the auction had already been well advanced.

The final auction size was on average $4.9 \%$ above the announcement. However, variability was high and was marked by a maximum undercut of $20 \%$ relative to the annuncement, and a maximum excess of $50 \%$ over the borrowing size announced.

\section{ii) From November 1991 to the end of 1999: announcement of a ceiling}

From November 1991 to the end of 1999, the Treasury announced a maximum on offer, reserving the right not to allot the full amount if insufficient bids were received at acceptable prices. At the same time it significantly increased the announced size on offer. The first announcement provided for a maximum of CHF 500 million and was increased up to a maximum of CHF 1.3 billion. The increase in the announced

56 Cf. Section 6.4.

57 For instance, the size of the October 1981 auction was set at CHF 150 million in spite of an announced intention to raise an amount of CHF 250 million. The rationale was to limit the issue at conditions that were judged to be unfavourable to the Treasury (cf. Boesiger 1982). When market conditions were thus unfavourable, a planned auction could even be cancelled at short notice. This in fact happened in October 1984. 
maximum size of borrowing compensated (partly) for the loss of flexibility due to the commitment to fixed dates of issuance included in the calendar.

In July 1993 the Treasury started running more than one auction at the same time. It began by offering three different reopenings simultaneously (tranches of existing bonds), which carried the same coupon but different maturities. It also stated that the borrowed sum would in total be limited to CHF 1 billion. Over the whole sample it pursued this practice on 78 different days. On 68 such occasions, two different bonds were put up for auction simultaneously. In the remaining ten, the Treasury offered three different securities at the same time.

Starting in August 1993, the Treasury often reserved additional own-account tranches at auctions, which provided a pool for tap issues from past issues. These securities may subsequently be issued at their original face value, maturity and coupon rate, but at market conditions and among relevant players. Not only the issue, but also the size of own-account tranches is announced before the auction. ${ }^{58}$ The reason why the Treasury offers its own tranches is to nurse the market, to profit from favourable conditions, to optimise its financing or to react to tensions. ${ }^{59}$ Their size varied from CHF 200 million to CHF 300 million and added up to CHF 35.9 billion over the whole sample period.

The average size of an auction announced, including own tranches, was CHF 1.033 billion. Effectively, much less than the announced maximum was usually raised. On average, CHF 495.966 million was borrowed (excluding own tranches), ranging from a minimum of CHF 78 million to a maximum of CHF 1.0 billion. ${ }^{60}$ Measured as a percentage, the average borrowing size undercut the announced maximum by $40 \%$. The most extreme negative deviation was $92 \%$, while the highest positive deviation was $54 \%$.

\section{iii) Since 2000: no announcement of borrowing size}

Since 2000, the Treasury has no longer provided any details about the size of the auctions in advance. Only the coupon and the maturity are determined prior to the auction day. Borrowing decreased with respect to the $1990 \mathrm{~s}$, while its volatility increased. The average bond size was CHF 0.430 billion. The smallest issue was as low as CHF 56.7 million and the largest as high as CHF 1.553 billion.

It is important to note that the announcements made in the calendar at the end of the year and the indications of issue size shortly before an auction (until 1999) were not intended as a firm commitment. Nor did the declared belief in regularity and predictability prevent auctions scheduled in the calendar from being cancelled at the discretion of those in charge. This occurred in 2008 and 2009, when ten auctions were cancelled. The reason was a reassessment of funding needs during the year, coupled with a politically imposed debt reduction that precluded unnecessary

58 In October 1995, for instance, the Treasury conducted a 'mini tender' with its own tranche of CHF 200 million of the 4.5\% 1993-2000 bond. More than CHF 195 million were placed at a price of $105.15 \%$, which corresponded to a yield of about $3.3 \%$. Cf. Finanz und Wirtschaft (1995).

59 For details cf. Annex I.

60 In the following, the numbers do not contain the tranches reserved for the Treasury's own account unless otherwise specified. 
borrowing. ${ }^{61}$ One unique event was the cancellation of the auction of the reopening of the 4.25\% 1997-2017 bond - no. 142 in Table 2 - after bids had been submitted. The Treasury motivated its decision by mentioning poor bidding that was not in line with the interest manifested by market participants in the run-up to the auction. ${ }^{62}$

\subsection{Bidding process}

The bidding process has shortened over time. We distinguish four phases here. Electronic bidding replaced phone bidding in 2001.

\subsubsection{Auction period}

\section{i) From 1980 to October 1991: variable}

The bidding process between January 1980 and October 1991 began with an announcement by the Treasury, several days ahead of the auction. While the auction day was fixed for Thursdays, the announcement day fluctuated widely from six to 22 days (10.49 days on average). The variable notification period coincides with the period when the announcement of the auction size was most precise, as described in the previous section.

Commercial banks, savings banks and security brokers would collect bids from their clients. Submissions from the public had to be made by Thursday noon by phone, and confirmed by fax to the SNB. Banks could submit their bids until 5 o'clock in the evening by phone, with confirmation by fax. The SNB would then inform the Treasury, which ultimately determined the issue price and size. The results were published on Friday morning on Reuters and in a press release.

\section{ii) From November 1991 to July 1994: three days}

From November 1991 until July 1994, the announcement period was shortened and fixed at three days. On the fourth Monday of the month of an auction week, the Treasury announced that it would offer a security the following Thursday. ${ }^{63}$

\section{iii) From August 1994 to the end of 1997: two days}

As of the August 1994 auction, the Treasury implemented several changes to its issuance procedure. The auction began with an announcement by the Treasury on the Tuesday of an auction week (not the Monday) that it would offer a security the following Thursday, with the subscription close set for noon. ${ }^{64}$ Auction results were already made public two hours after the close of the auction, not just on the following day.

61 By contrast, the US Treasury has never cancelled an auction, merely because it has had no immediate need for additional funds since the 1970s. Any undesirably large cash balances resulting from sticking to selling securities on a regular and predictable basis was managed through the Treasury Tax and Loan programme, by reducing the amounts offered, or by terminating a series (cf. Garbade 2007).

62 This suggests that the price established at the auction was below the Treasury's (hidden) reserve price. A reserve price means that the auctioneer will not sell the object for a price below it.

63 There is no official when-issued market. However, in 1992 a grey market for the time between the announcement of a new issue and the auction emerged.

64 The March 1997 auction was closed at 10 o'clock because of the beginning of the Easter holidays. 
Furthermore, the underwriting and placing commission paid to banks was reduced from $0.5 \%$ to $0.1 \%$.

\section{iv) From January 1998 to today: one day}

The auction procedure was changed again in January 1998. The objective was to increase market liquidity and - given its volatility - to reduce once more the time lag between the announcement and the auction deadline. To this end, the auction close was set for Wednesday, a day earlier than hitherto customary. As a rule an auction was announced on every fourth Tuesday of the month. The next day, the bidding window opened at 9.30 in the morning and closed at noon. As of 13 July 2011, the auction window for Swiss Confederation bonds was shortened by one hour. Auctions now begin at 9.30 am and end one hour earlier at $11.00 \mathrm{am}$.

\subsubsection{Electronic platform as of March 2001}

From a technical point of view, the most significant change to the bidding process was implemented on 28 March 2001. Since this date, all Swiss Treasury auctions of negotiable debt (i.e. including money-market debt) have been conducted on the electronic Eurex Repo platform which is directly linked, via SIC Swiss Interbank Clearing, to the clearing and settlement facility of SIS SegaInterSettle AG. Through linkages with the clearing systems, full automation of settlement procedures is provided, promoting the efficiency of back office activities in the participating banks. ${ }^{65}$ The auctions have been open to all market participants, including non-domestic ones, which have access to the Swiss value chain provided by Six Ltd. and Eurex respectively. The electronic platform simplified the auction process for the SNB, the Treasury and the bidders. It enhanced efficiency, reduced costs and increased process reliability. Electronic bidding did not change the sealed-bid character of the auction. ${ }^{66}$ Details of individual bids (the book) are visible to the SNB and the Treasury and to no one else. ${ }^{67}$

\subsection{Cut-off price}

After bidding has closed, the allocation rule gives precedence to non-competitive bids that are awarded fully with certainty (subject to quantity limits, as discussed in section 6.2), and subsequently to competitive bids in order of descending price until the amount offered is exhausted. The lowest accepted price, which is established by the Treasury, is the cut-off price. ${ }^{68}$ All auction awards are made at this price. Bids specifying prices above the clearing price level are guaranteed to be filled in full; bids below it are rejected. Prior to March 2001, the allocation at the stop was

65 The SNB and the Treasury were the first users of Eurex Repo for their auctions. System participants were entitled to take part in Treasury auctions, were given access to the repo interbank market, and a direct connection with the SNB for liquidity procurement.

66 The electronic bid system set an upper limit for a single offer of CHF 100 million. However, this limit has been established purely for settlement reasons.

67 The electronic auctions for money-market debt, which started on 27 February 2001, begin in the early morning each Tuesday and end at $11 \mathrm{am}$.

68 The market clearing price is also called the stop-out price or the 'stop', indicating the price at which the auction stopped. 
rationed (with few exceptions) according to the ratio of the quantity of securities that remained to be sold at the stop to the quantity bid at the stop. The lowest allocation at the cut-off price was $26.93 \%$ (i.e. a cut of $73.04 \%$ of the bids posted at the lowest accepted price). On average, however, until February $200192.33 \%$ of the bids posted at the lowest accepted price were accepted. While allocation on a pro-rata basis can be made at any time, all bids at the cut-off price have been fully allocated since the introduction of electronic bidding.

Table 1 presents a fictitious example, illustrating the determination of the cut-off price. Let us assume that the Treasury announces that it intends to auction CHF 250 million. Non-competitive bids amount to CHF 50 million. They are filled in full with certainty. Competitive bids are then ranked according to price. In this example, the Treasury would accept bids of $102.0 \%$ until $101.2 \%$ (the cut-off price), which add up to CHF 280 million. Offers at $101.1 \%$ and lower are not taken into account. Until February 2001, bids at the cut-off price would be filled on a pro-rata basis. Here, bids at $101.2 \%$ would be allocated $50 \%$ of the amount specified.

Table 1: EXAMPLE OF PRICE DETERMINATION

\begin{tabular}{ccc}
\hline Issue price (in ) & Bids (in CHF millions) & Cumulated bids (in CHF millions) \\
\hline Non-competitive & 50 & 50 \\
102.0 & 10 & 60 \\
101.9 & 17 & 77 \\
101.8 & 17 & 94 \\
101.7 & 15 & 109 \\
101.6 & 20 & 129 \\
101.5 & 36 & 165 \\
101.4 & 25 & 190 \\
101.3 & 30 & 220 \\
$101.2 *$ & 60 & 280 \\
101.1 & 60 & 340 \\
101.0 & 78 & 518 \\
etc. & $\ldots$ & $\ldots$ \\
\hline
\end{tabular}

* Successful bidders pay the cut-off price, which is the price of the lowest accepted bid.

\subsection{Announcement of results}

The announcement of auction results has always included:

- Coupon

- Maturity

- Total amount borrowed

- Issue price

- Annual yield

- Non-competitive bids ${ }^{69}$

69 This information was withheld in the first four auctions. 
Additional information has been provided over time:

- Since the December 1992 auction, the settlement date has been announced.

- Beginning with the August 1993 auction, the Treasury mentions the amount of its own tranches, if any.

- Until September 1993, the announcement would only state whether bids at the cut-off price had been awarded fully or on a pro-rata basis. ${ }^{70}$ Starting with the auction scheduled for 28 October 1993, the result announcements have included the exact allotment rate in the final price category as well as the total subscription value (total price-quantity bids).

The electronic auction system shortened the time in which auction results are made public to participants (the 'turnaround time'), reducing it significantly to about 15 minutes. Results are released through EUREX, and through Bloomberg and Reuters within 10 minutes. They are also posted on the websites of the FFA and SNB a little later.

\section{Conclusions}

Prior to 1980, the Swiss Treasury sold government bonds by syndicated fixed-price subscription offerings. Since then it has applied the uniform-price auction format as the sale method for short-term debt register claims and medium to long-term bonds. While the rationale for abandoning syndicated offering is well documented and resides in growing discontent with it at a time of increased market volatility, this is not the case regarding the choice of the auction format. Revenue arguments, while important, do not seem to have been (explicitly) preponderant. It seems that considerations associated with the equal treatment of bidders, the unification of the primary and the secondary markets, and an encouragement to broader participation thanks to this format's simplicity, were decisive factors in the authorities' choice.

Although the base frame of the auction has remained unimpaired, some rules have undergone a permanent change. Most modifications were made during the early 1990s during mounting financial pressures on the government. As a general trend, the information conveyed to the market ahead of the auction has been steadily cut back. This is particularly true of auction size. This has been partly offset by an announcement of the intended gross and net borrowing size in a yearly calendar. Another trend has been the specification and reduction of the time lag between the announcement of an auction's terms and the closing day. In the same vein, the turnaround time has been increasingly shortened. A further innovation was the conduct of two or three auctions simultaneously. Another permanent change has been the transition from phone to electronic bidding, which has improved the efficiency of the auction process and eliminated cuts in the allocation at the stop. The limit amount to be bid in the non-competitive tender was raised from CHF 20,000 to CHF 100,000. In a move that was interpreted as an experiment, this limit was removed altogether for half a year, but then subsequently reintroduced.

70 There was no indication whether there had been a reduced allocation at the cut-off price in the first and fourth auction. 
Unlike in other countries, (direct) participation in the auctions has been open to a wide range of interested parties. Participating institutions play an important role in the government securities market without asking for any compensation. From 1980 to the end of 2014 the SNB ran 356 auctions of government bonds on behalf of the Treasury, raising CHF 149.435 billion. All auctions were subscribed.

\section{Annex I: Major changes}

1980

- On Monday, 7 January, the first Swiss Confederation bond auction was announced. The auction was held on Thursday, 17 January.

- In April, the first callable bond was auctioned. Callable bonds were issued irregularly until 1992.

- The prospectus for the October auction for the first time contained information about non-competitive bids up to CHF 20,000.

\section{1}

- In the March auction, the prospectus mentioned for the first time that the Swiss Confederation would reserve the right to reduce the size of the issue.

\section{2}

- In December, the Treasury announced that it would henceforth reserve the right to increase or decrease the amount of the issue by a maximum of $20 \%$.

\section{6}

- In March, the limit for a non-competitive bid was raised to CHF 100,000.

- In November, the Treasury stated that it would henceforth reserve the right to increase or decrease the amount of the issue.

\section{9}

- In December, the Treasury concluded the first swap transaction in the form of an interest-rate swap based on a nominal amount of CHF 237 million.

\section{1}

- In October, the Treasury began to issue fungible bonds by auctioning tranches of existing bonds (reopening policy) with the aim of increasing the final size of bonds to improve their tradeability and thus market depth and liquidity.

- In November, three major changes were made. The Treasury began increasing the size of its issuances in order to enhance market depth and liquidity; in order to increase its flexibility in setting the final auction size, the Treasury switched from announcing a range to be borrowed to a prospective maximum. Auctions were also systematically announced on Mondays. The auction day remained unchanged, namely the Thursday of the same week. 
- At the end of April, the Treasury began issuing an official auction calendar and stepped up the frequency of issuance.

- SOFFEX started CONF Futures trading on 29 May. CONF Futures are based on notional long-term debt instruments issued by the Swiss Confederation with a term of eight to 13 years, and a notional coupon rate of $6 \%$. The issue amount is at least CHF 500 million. Delivery day is the tenth calendar day of the delivery month if this day is an exchange day; otherwise it is the next exchange day subsequent to that day. The last trading day is two exchange days prior to the delivery day of the relevant month. The contract value is standardised at CHF 100,000 .

- Beginning with the first auction under the calendar in May, the issue prospectus no longer included a limit to non-competitive participants. Instead, it stated that offers without indication of price would be invoiced at the cut-off price. This practice was pursued for the following six auctions. After having allotted CHF 0.678 billion to non-competitive bidders in the November auction (the largest allotment to non-competitive participants ever), the December auction reinstalled the limit of CHF 100,000 per non-competitive bidder.

- On 15 October the Confederation started issuing Confederation time deposits ('Bundesfestgelder') as an additional fund-raising instrument with a term from one to three years and a minimum amount of CHF 10,000. Interest was set by the Treasury according to the conditions of the market. Subscriptions were placed at post office counters.

- In the October auction, the last callable bond was issued.

- In November, the first 'jumbo' bond was auctioned, reaching a size of CHF 0.998 billion.

\section{3}

- In July the Treasury started running two to three auctions simultaneously. Such a policy can provide different benefits. By offering different maturities simultaneously, for instance, a 'sounder', cheaper and higher funding volume is more likely. Addressing a variety of investors may broaden the investor base, such as banks interested in short to medium-term maturities on the one hand, and institutional investors with a liking for long-term securities on the other. In addition, real demand for the underlying assets may generate more favourable conditions for the Treasury. Trying to raise the same volume of funds by one single security instead may call for the Treasury to offer price discounts to a narrow set of investors.

- In the August auction, the Treasury began reserving tranches of bonds on issue for its own purposes. The Treasury stated that it would itself reserve the right to place the entire tranche or only a part of it on the market at a subsequent date. There are several reasons for subscribing to own issues. One is that the Treasury may want to supply public entities affiliated to the Confederation with funds in case of need (such as SUVA or AHV). It also increases its flexibility to act according to market conditions. Own-account tranches may also be placed within a few hours in case of demand, or if there is a threat of market distortions at maturity of futures contracts. Another reason is for securities lending, or so as to 
intervene when a single bank subscribes to a dominant part of an issue and risks disrupting the market by a squeeze, which in this case may be met by offering own tranches. ${ }^{71}$ In general, the reservation of tranches from its auctions increased the Treasury's flexibility to take action between its self-chosen dates of issuance, which are fixed.

- From October onwards, both the total amount of bids and the allotment rate in the final price category were announced.

\section{4}

- Soffex expanded its range of products for risk management by introducing options on futures of Swiss Confederation bonds on 28 January.

- The August auction implemented several changes. The subscription period was shortened by one and a half days, the announcement of new auctions was postponed from Monday to Tuesday, and the close of bids was advanced from Thursday evening (for banks) to Thursday noon. The turnaround time was also shortened to two hours, whereas auction results were previously only made public the following day. The underwriting and placing commission was reduced to $0.1 \%$ from the previous level of $0.5 \%$ of the nominal value of the bond paid to banks. This way, the prices of outstanding bonds were less (negatively) affected after a reopening was announced. The commission was later removed altogether.

\section{6}

- Eurex began COMI Futures trading on 21 June. A COMI Futures was a contract on a notional bond of the Swiss Confederation with a remaining term of three to eight years (less one day) and an interest rate of $6 \%$. The par value of any such contract was CHF 100,000.

\section{7}

- May auction: For the first time the issue was securitised permanently and exclusively in a global certificate. Holders only had a right to share the co-ownership in the global certificate.

\section{8}

- Beginning with the January auction, the subscription close was brought forward by one day to Wednesday noon.

- In the spring, the Treasury successfully sold a 30-year bond. Until then maturities had ranged between eight and 15 years.

- To implement its announced commitment to long-term securities borrowing, the Treasury issued a 50-year government bond in November. This decision broke new ground in the maturity of debt issued by sovereign borrowers. Most governments in industrialised countries had issued bonds of up to 30 years maturity. Switzerland was the first country in recent memory to issue a 50-year bond, in a move intended as experiment. It was targeted at those Swiss investors who

71 There is no other specific anti-squeeze measure in Switzerland. There are potentially other anti-squeeze measures, such as position reporting provisions, position limits, special repo or securities lending facilities, or the requirement of cash settlement on the futures market. 
are required by law to earn a minimum $4 \%$ on their funds under management. Although envisaged as an experiment, the issue was not unsuccessful and had a coverage of $1.4 .^{72}$

1999

- Eurex stopped trading the COMI Future after the contract settlement date on 11 June. The reason was the steady decline in trading volume, which was mainly due to the lack of liquidity in the cash market in this maturity segment. The yield curve of Swiss federal government issues was extremely flat, and investors preferred the long end of the market. Moreover, the volume of issues in the fiveyear range was relatively low. The Swiss stamp duty in low-interest phases had an additional dampening effect on trading in the cash market.

- At the end of October, the issuance of time deposits ('Bundesfestgelder') was discontinued.

- Bids at the auction of the 4.25\% 1997-2017 bond held on 24 November were subsequently cancelled and no allocation was performed.

\section{1}

- From March onwards, Swiss Treasury auctions were conducted on the electronic Eurex Repo platform.

- From then on, while still possible, bids at the cut-off price were no longer filled on a pro-rata basis as had customarily been the case during phone bidding (with few exceptions), but were allocated the full bid amount. Also, for settlement reasons, auction announcements stated that a single offer was not allowed to exceed CHF 100 million.

2007

- On 7 December, the issue calendar in 2008 held out net bond redemptions of approximately CHF 0.4 billion for the first time, suggesting a (slight) decrease in outstanding government bonds.

\section{9}

- The calendar for 2010 held out the prospect of optional dates for the auctions. In 2012 the Treasury exercised the option and forewent the last two auctions (November and December) envisaged by the calendar.

\section{1}

- On 13 July, the auction window was shortened to one hour.

72 It was not Switzerland's first attempt to tap into this segment of the market. In 1909 it issued a 50 -year bond with a $3.5 \%$ coupon. Other countries had also issued ultra-long bonds in the past. For example, in June 1919 the UK issued two ultra-long gilts with maturities of 57 and 71 years respectively (cf. Blommestein and Wehinger 2007). 


\begin{tabular}{|c|c|c|c|c|c|c|c|c|c|}
\hline No.* & Value date & Amortisation & $\begin{array}{l}\text { Coupon } \\
\text { (in \%) }\end{array}$ & $\begin{array}{c}\text { Reopen- } \\
\text { ing? } \\
(\mathrm{Y} / \mathrm{N})\end{array}$ & $\begin{array}{l}\text { Auction } \\
\text { size }\end{array}$ & $\begin{array}{l}\text { Competitive } \\
\text { bid } \\
\text { (in } \mathrm{CHF} \text { mi }\end{array}$ & $\begin{array}{l}\text { Non-com- } \\
\text { petitive bid } \\
\text { lions) }\end{array}$ & $\begin{array}{c}\text { Own } \\
\text { tranche }\end{array}$ & $\begin{array}{c}\begin{array}{c}\text { Cut-off } \\
\text { price }\end{array} \\
\text { (in \%) }\end{array}$ \\
\hline 1 & 05.02 .1980 & 05.02 .1992 & 4.50 & No & 205 & 430.405 & 38.047 & 0 & 100.20 \\
\hline 2 & 14.05 .1980 & 14.05 .1990 & 5.25 & No & 255 & 523.04 & 30.189 & 0 & 100.30 \\
\hline 3 & 01.07 .1980 & 01.07 .1990 & 4.75 & No & 260 & 472.545 & 15.377 & 0 & 100.00 \\
\hline 4 & 05.09 .1980 & 05.09 .1992 & 4.50 & No & 246 & 290.076 & 8.858 & 0 & 98.80 \\
\hline 5 & 03.11 .1980 & 03.11 .1990 & 4.75 & No & 260 & 362.452 & 12.291 & 0 & 99.00 \\
\hline 6 & 06.04 .1981 & 06.04 .1993 & 5.75 & No & 270 & 580.372 & 42.156 & 0 & 101.20 \\
\hline 7 & 01.06 .1981 & 01.06 .1993 & 5.75 & No & 240 & 382.881 & 19.987 & 0 & 99.00 \\
\hline 8 & 24.08 .1981 & 24.08 .1993 & 5.75 & No & 260 & 323.423 & 19.395 & 0 & 100.50 \\
\hline 9 & 04.11 .1981 & 04.11 .1990 & 6.25 & No & 150 & 319.236 & 22.536 & 0 & 101.00 \\
\hline 10 & 11.01 .1982 & 11.01 .1991 & 5.75 & No & 255 & 532.935 & 25.852 & 0 & 102.50 \\
\hline 11 & 05.04 .1982 & 05.04 .1989 & 5.25 & No & 165 & 413.478 & 21.308 & 0 & 102.00 \\
\hline 12 & 24.05 .1982 & 24.05 .1997 & 5.00 & No & 205 & 355.903 & 17.681 & 0 & 102.30 \\
\hline 13 & 15.07 .1982 & 15.07 .1991 & 5.00 & No & 270 & 359.387 & 9.934 & 0 & 98.80 \\
\hline 14 & 20.07 .1982 & 20.07 .1994 & 5.25 & No & 215 & 336.951 & 19.376 & 0 & 100.60 \\
\hline 15 & 15.09 .1982 & 15.09 .1994 & 4.50 & No & 255 & 395.559 & 15.278 & 0 & 100.10 \\
\hline 16 & 22.11 .1982 & 22.11 .1997 & 4.25 & No & 275 & 470.568 & 17.429 & 0 & 102.00 \\
\hline 17 & 24.01 .1983 & 24.01 .1995 & 4.00 & No & 295 & 393.789 & 18.165 & 0 & 101.00 \\
\hline 18 & 15.04 .1983 & 15.04 .1993 & 4.25 & No & 290 & 370.669 & 14.872 & 0 & 99.80 \\
\hline 19 & 04.07 .1983 & 04.07 .1995 & 4.50 & No & 200 & 448.434 & 21.116 & 0 & 100.70 \\
\hline 20 & 05.09 .1983 & 05.09 .1995 & 4.50 & No & 245 & 341.345 & 14.447 & 0 & 99.10 \\
\hline 21 & 03.11 .1983 & 03.11 .1993 & 4.50 & No & 275 & 434.649 & 22.237 & 0 & 100.30 \\
\hline 22 & 09.01 .1984 & 09.01 .1994 & 4.50 & No & 300 & 442.653 & 20.016 & 0 & 100.40 \\
\hline 23 & 01.03 .1984 & 01.03 .1993 & 4.50 & No & 289 & 479.011 & 20.282 & 0 & 99.60 \\
\hline 24 & 10.04 .1984 & 10.04 .1994 & 4.50 & No & 295 & 368.854 & 16.132 & 0 & 99.30 \\
\hline 25 & 01.06 .1984 & 01.06.1996 & 4.75 & No & 275 & 299.34 & 20.942 & 0 & 100.00 \\
\hline 26 & 17.07.1984 & 17.07.1994 & 4.75 & No & 275 & 348.177 & 21.724 & 0 & 100.00 \\
\hline 27 & 11.09 .1984 & 11.09.1996 & 4.75 & No & 230 & 373.84 & 17.634 & 0 & 99.80 \\
\hline 28 & 07.01 .1985 & 07.01 .1997 & 4.75 & No & 280 & 509.901 & 20.577 & 0 & 100.50 \\
\hline 29 & 11.02 .1985 & 11.02 .2000 & 4.75 & No & 264 & 364.054 & 13.511 & 0 & 99.90 \\
\hline 30 & 10.04 .1985 & 10.04 .1997 & 5.00 & No & 290 & 694.665 & 33.55 & 0 & 101.40 \\
\hline 31 & 31.05 .1985 & 31.05 .1996 & 4.75 & No & 300 & 505.146 & 12.009 & 0 & 100.00 \\
\hline 32 & 21.10 .1985 & 21.10 .1999 & 4.75 & No & 289 & 627.6 & 16.185 & 0 & 101.10 \\
\hline 33 & 06.01 .1986 & 06.01 .2001 & 4.75 & No & 289 & 697.31 & 18.893 & 0 & 102.10 \\
\hline 34 & 08.04.1986 & 08.04 .2001 & 4.25 & No & 270 & 625.431 & 12.558 & 0 & 101.00 \\
\hline 35 & 02.12 .1986 & 02.12 .2011 & 4.25 & No & 200 & 219.101 & 10.135 & 0 & 99.80 \\
\hline 36 & 25.02 .1987 & 25.02 .2012 & 4.25 & No & 225 & 281.412 & 13.782 & 0 & 101.80 \\
\hline 37 & 25.09 .1987 & 25.09 .1997 & 4.00 & No & 120 & 159.825 & 4.514 & 0 & 97.70 \\
\hline 38 & 12.01 .1988 & 12.01 .1998 & 4.00 & No & 285 & 436.686 & 16.309 & 0 & 101.60 \\
\hline
\end{tabular}




\begin{tabular}{|c|c|c|c|c|c|c|c|c|c|}
\hline No.* & Value date & Amortisation & $\begin{array}{l}\text { Coupon } \\
\text { (in \%) }\end{array}$ & $\begin{array}{l}\text { Reopen- } \\
\text { ing? } \\
(\mathrm{Y} / \mathrm{N})\end{array}$ & $\begin{array}{l}\text { Auction } \\
\text { size }\end{array}$ & $\begin{array}{c}\text { Competitive } \\
\text { bid } \\
\text { (in CHF m }\end{array}$ & $\begin{array}{l}\text { Non-com- } \\
\text { petitive bid } \\
\text { llions) }\end{array}$ & $\begin{array}{c}\text { Own } \\
\text { tranche }\end{array}$ & $\begin{array}{l}\begin{array}{c}\text { Cut-off } \\
\text { price }\end{array} \\
\text { (in \%) }\end{array}$ \\
\hline 39 & 05.02 .1988 & 05.02.1999 & 4.00 & No & 245 & 258.371 & 15.174 & 0 & 100.50 \\
\hline 40 & 12.04 .1988 & 12.04 .1995 & 4.00 & No & 220 & 367.473 & 15.255 & 0 & 101.10 \\
\hline 41 & 11.01 .1989 & 11.01 .2001 & 4.25 & No & 235 & 269.465 & 19.274 & 0 & 100.40 \\
\hline 42 & 06.04 .1989 & 06.04 .1997 & 4.75 & No & 215 & 286.224 & 19.346 & 0 & 99.30 \\
\hline 43 & 24.08 .1989 & 24.08 .1997 & 5.25 & No & 285 & 482.576 & 53.441 & 0 & 101.00 \\
\hline 44 & 18.10 .1989 & 18.10 .1998 & 5.50 & No & 237 & 325.186 & 27.136 & 0 & 100.00 \\
\hline 45 & 08.01 .1990 & 08.01 .1999 & 5.50 & No & 200 & 227.844 & 14.251 & 0 & 98.70 \\
\hline 46 & 08.03.1990 & 08.03 .2000 & 6.25 & No & 293 & 300.194 & 18.489 & 0 & 98.00 \\
\hline 47 & 09.05 .1990 & 09.05 .2000 & 6.50 & No & 249 & 283.408 & 19.812 & 0 & 98.00 \\
\hline 48 & 16.07 .1990 & 16.07.1999 & 6.50 & No & 277 & 402.048 & 30.557 & 0 & 101.00 \\
\hline 49 & 22.01 .1991 & 22.01 .2001 & 6.75 & No & 324 & 428.556 & 50.097 & 0 & 100.40 \\
\hline 50 & 15.03 .1991 & 15.03 .2001 & 6.25 & No & 206 & 309.199 & 28.534 & 0 & 98.90 \\
\hline 51 & 17.05 .1991 & 17.05 .2003 & 6.25 & No & 302 & 382.01 & 26.186 & 0 & 100.30 \\
\hline \multirow[t]{2}{*}{52} & 15.07 .1991 & 15.07 .2002 & 6.25 & No & 302 & 377.658 & 30.543 & 0 & 100.00 \\
\hline & 05.09 .1991 & 05.09 .2003 & 4.50 & No & 0 & - & 0 & 0 & - \\
\hline 53 & 16.10 .1991 & 16.07.1999 & 6.50 & Yes & 220 & 359.775 & 21.515 & 0 & 100.20 \\
\hline 54 & 22.01 .1992 & 22.01 .2001 & 6.75 & Yes & 500 & 736.865 & 34.464 & 0 & 100.10 \\
\hline 55 & 05.02 .1992 & 05.02 .2002 & 6.50 & No & 600 & $1 ‘ 379.208$ & 126.636 & 0 & 101.50 \\
\hline 56 & 10.03 .1992 & 05.02 .2002 & 6.50 & Yes & 800 & $1 ‘ 244.495$ & 80.286 & 0 & 101.00 \\
\hline 57 & 10.04 .1992 & 10.04 .2004 & 6.50 & No & 704 & 984.43 & 27.188 & 0 & 99.00 \\
\hline 58 & 11.06 .1992 & 11.06 .2003 & 6.75 & No & 505 & 562.81 & 68.42 & 0 & 98.70 \\
\hline 59 & 09.07 .1992 & 09.07 .2001 & 7.00 & No & 500 & $1^{\prime} 154.330$ & 113.074 & 0 & 99.70 \\
\hline 60 & 06.08 .1992 & 09.07 .2001 & 7.00 & Yes & 500 & 877.431 & 140.39 & 0 & 99.30 \\
\hline 61 & 10.09 .1992 & 10.09 .2005 & 7.00 & No & 700 & $2 ‘ 568.880$ & 222.378 & 0 & 100.60 \\
\hline 62 & 08.10 .1992 & 11.06 .2003 & 6.75 & Yes & 700 & 817.48 & 232.979 & 0 & 102.40 \\
\hline 63 & 05.11 .1992 & 05.11 .2006 & 6.25 & No & 700 & $1^{`} 086.920$ & 154.599 & 0 & 100.60 \\
\hline 64 & 07.01 .1993 & 07.01 .2003 & 6.25 & No & 998 & 748.825 & 678.056 & 0 & 101.80 \\
\hline 65 & 07.01 .1993 & 07.01 .2003 & 6.25 & Yes & 611 & 698.97 & 47.365 & 0 & 104.30 \\
\hline 66 & 11.02 .1993 & 11.02 .1998 & 5.25 & No & 800 & $1 ‘ 436.085$ & 52.351 & 0 & 100.20 \\
\hline 67 & 11.03 .1993 & 11.03 .2000 & 5.00 & No & 500 & $1 ` 073.705$ & 56.205 & 0 & 101.70 \\
\hline 68 & 08.04.1993 & 08.04 .2006 & 4.50 & No & 477 & 772.86 & 24.605 & 0 & 100.30 \\
\hline 69 & 06.05 .1993 & 08.04 .2006 & 4.50 & Yes & 200 & 454.62 & 11.22 & 0 & 99.50 \\
\hline 70 & 10.06 .1993 & 10.06 .2000 & 4.50 & No & 550 & 654.85 & 15.328 & 0 & 99.20 \\
\hline 71 & 08.07.1993 & 08.07 .2002 & 4.50 & No & 780 & 806.88 & 57.927 & 0 & 100.40 \\
\hline 72 & 05.08 .1993 & 10.06 .2000 & 4.50 & Yes & 637 & 709.98 & 23.564 & 0 & 100.20 \\
\hline 73 & 05.08 .1993 & 08.07 .2002 & 4.50 & Yes & 206 & 258.56 & 13.915 & 0 & 100.20 \\
\hline 74 & 05.08 .1993 & 08.04 .2006 & 4.50 & Yes & 157 & 160.01 & 10.03 & 0 & 100.00 \\
\hline 75 & 09.09 .1993 & 08.07 .2002 & 4.50 & Yes & 642 & $1 ‘ 402.920$ & 40.07 & 200 & 100.50 \\
\hline 76 & 09.09.1993 & 08.04 .2006 & 4.50 & Yes & 308 & 467.5 & 16.33 & 200 & 100.00 \\
\hline 77 & 07.10 .1993 & 07.10 .2004 & 4.50 & No & 862 & $1 ‘ 359.610$ & 37.891 & 200 & 100.30 \\
\hline 78 & 11.11 .1993 & 10.06 .2000 & 4.50 & Yes & 390 & 536.59 & 21.27 & 200 & 103.10 \\
\hline
\end{tabular}




\begin{tabular}{|c|c|c|c|c|c|c|c|c|c|}
\hline No.* & Value date & Amortisation & $\begin{array}{l}\text { Coupon } \\
\text { (in \%) }\end{array}$ & $\begin{array}{l}\text { Reopen- } \\
\text { ing? } \\
(\mathrm{Y} / \mathrm{N})\end{array}$ & $\begin{array}{l}\text { Auction } \\
\text { size }\end{array}$ & $\begin{array}{l}\text { Competitive } \\
\text { bid } \\
\text { (in } \mathrm{CHF} \text { mi }\end{array}$ & $\begin{array}{l}\text { Non-com- } \\
\text { petitive bid } \\
\text { llions) }\end{array}$ & $\begin{array}{c}\text { Own } \\
\text { tranche }\end{array}$ & $\begin{array}{c}\text { Cut-off } \\
\text { price } \\
\text { (in \%) }\end{array}$ \\
\hline 79 & 11.11 .1993 & 08.04 .2006 & 4.50 & Yes & 525 & 701.6 & 14.34 & 0 & 103.10 \\
\hline 80 & 06.01 .1994 & 06.01 .2014 & 4.25 & No & 676 & 853.01 & 16.039 & 200 & 98.20 \\
\hline 81 & 10.02 .1994 & 07.10 .2004 & 4.50 & Yes & 930 & $1 ` 471.925$ & 34.409 & 200 & 103.00 \\
\hline 82 & 10.03 .1994 & 08.07 .2002 & 4.50 & Yes & 444 & 656.56 & 21.088 & 0 & 101.20 \\
\hline 83 & 10.03 .1994 & 10.03.1999 & 4.00 & No & 353 & 831.24 & 32.62 & 0 & 100.00 \\
\hline 84 & 08.04.1994 & 10.03 .1999 & 4.00 & Yes & 334 & 927.6 & 30.64 & 0 & 99.20 \\
\hline 85 & 08.04 .1994 & 08.04 .2006 & 4.50 & Yes & 502 & 608.2 & 17.82 & 0 & 99.30 \\
\hline 86 & 13.05 .1994 & 10.03 .1999 & 4.00 & Yes & 220 & 293.72 & 23.555 & 0 & 98.40 \\
\hline 87 & 13.05 .1994 & 07.10 .2004 & 4.50 & Yes & 360 & 555.35 & 22.255 & 0 & 97.30 \\
\hline 88 & 07.07.1994 & 11.03 .2000 & 5.00 & Yes & 283 & 371.465 & 26.053 & 0 & 99.80 \\
\hline 89 & 11.08 .1994 & 11.03 .2000 & 5.00 & Yes & 318 & 432.285 & 19.701 & 0 & 100.30 \\
\hline 90 & 11.08 .1994 & 07.10 .2004 & 4.50 & Yes & 357 & 367.8 & 5.665 & 0 & 95.10 \\
\hline 91 & 08.09.1994 & 11.03 .2000 & 5.00 & Yes & 207 & 304.43 & 6.905 & 0 & 98.40 \\
\hline 92 & 08.09.1994 & 07.10 .2004 & 4.50 & Yes & 200 & 332.5 & 6.44 & 0 & 92.40 \\
\hline 93 & 07.10 .1994 & 11.02 .1998 & 5.25 & Yes & 354 & 530.83 & 6.918 & 0 & 100.00 \\
\hline 94 & 07.10 .1994 & 07.10 .2001 & 5.50 & No & 685 & $1 ` 405.715$ & 30.37 & 0 & 100.00 \\
\hline 95 & 10.11.1994 & 10.11 .1996 & 5.00 & No & 555 & 685.6 & 45.316 & 0 & 99.90 \\
\hline 96 & 06.01 .1995 & 06.01 .2005 & 5.50 & No & 726 & $1 ` 467.480$ & 25.342 & 0 & 101.00 \\
\hline 97 & 06.01 .1995 & 07.10 .2001 & 5.50 & Yes & 455 & 663.57 & 26.347 & 0 & 101.50 \\
\hline 98 & 08.03.1995 & 06.01 .2005 & 5.50 & Yes & 533 & $1^{\prime} 117.990$ & 28.585 & 0 & 101.50 \\
\hline 99 & 10.04 .1995 & 11.03 .2000 & 5.00 & Yes & 640 & $1^{\prime} 681.115$ & 35.817 & 0 & 100.90 \\
\hline 100 & 08.06.1995 & 08.04 .2006 & 4.50 & Yes & 536 & 1 '599.150 & 20.082 & 0 & 96.80 \\
\hline 101 & 10.08 .1995 & 08.04 .2006 & 4.50 & Yes & 500 & $1 ‘ 351.450$ & 30.79 & 0 & 97.90 \\
\hline 102 & 12.10 .1995 & 06.01 .2014 & 4.25 & Yes & 104 & 130.5 & 11.58 & 0 & 92.75 \\
\hline 103 & 08.01 .1996 & 08.01 .2008 & 4.25 & No & $1^{‘} 000.000$ & $4^{‘} 630.270$ & 46.045 & 200 & 102.45 \\
\hline 104 & 08.01 .1996 & 08.07 .2002 & 4.50 & Yes & 314 & 496.05 & 11.5 & 0 & 105.40 \\
\hline 105 & 05.02 .1996 & 08.01 .2008 & 4.25 & Yes & 78 & 201.67 & 10.672 & 0 & 100.75 \\
\hline 106 & 10.04 .1996 & 08.07 .2002 & 4.50 & Yes & 455 & 545.755 & 25.589 & 0 & 104.80 \\
\hline 107 & 10.06 .1996 & 10.06 .2000 & 4.50 & Yes & 230 & 271.12 & 11.645 & 0 & 104.50 \\
\hline 108 & 10.06 .1996 & 10.06 .2007 & 4.50 & No & 302 & 424.35 & 20.061 & 0 & 99.60 \\
\hline 109 & 08.08.1996 & 08.07 .2002 & 4.50 & Yes & 317 & 586.92 & 17.07 & 0 & 103.10 \\
\hline 110 & 08.08.1996 & 10.06 .2007 & 4.50 & Yes & 459 & 592.04 & 7.865 & 0 & 100.35 \\
\hline 111 & 07.10 .1996 & 06.01 .2005 & 5.50 & Yes & 310 & 473.7 & 15.878 & 200 & 111.50 \\
\hline 112 & 07.10 .1996 & 08.01 .2008 & 4.25 & Yes & $1^{`} 000.000$ & $1 ‘ 578.500$ & 20.425 & 200 & 100.60 \\
\hline 113 & 13.01 .1997 & 10.06 .2007 & 4.50 & Yes & 766 & 957.63 & 39.385 & 300 & 103.45 \\
\hline 114 & 06.02 .1997 & 10.06 .2007 & 4.50 & Yes & 904 & $1^{\prime} 756.180$ & 25.85 & 0 & 105.45 \\
\hline 115 & 10.04 .1997 & 10.06 .2000 & 4.50 & Yes & 314 & 559.2 & 9.213 & 300 & 106.90 \\
\hline 116 & 10.04 .1997 & 06.01 .2014 & 4.25 & Yes & 256 & 512.55 & 13.716 & 300 & 98.50 \\
\hline 117 & 05.06.1997 & 05.06 .2017 & 4.25 & No & 228 & 460.75 & 18.968 & 200 & 99.00 \\
\hline 118 & 07.08.1997 & 07.08 .2010 & 3.50 & No & 561 & $1^{`} 026.550$ & 15.035 & 200 & 97.65 \\
\hline 119 & 09.10 .1997 & 08.01 .2008 & 4.25 & Yes & 712 & $1^{\prime} 769.060$ & 13.765 & 300 & 105.60 \\
\hline
\end{tabular}




\begin{tabular}{|c|c|c|c|c|c|c|c|c|c|}
\hline No.* & Value date & Amortisation & $\begin{array}{l}\text { Coupon } \\
\text { (in \%) }\end{array}$ & $\begin{array}{l}\text { Reopen- } \\
\text { ing? } \\
(\mathrm{Y} / \mathrm{N})\end{array}$ & $\begin{array}{l}\text { Auction } \\
\text { size }\end{array}$ & $\begin{array}{l}\text { Competitive } \\
\text { bid } \\
\text { (in } \mathrm{CHF} \text { m }\end{array}$ & $\begin{array}{l}\text { Non-com- } \\
\text { petitive bid } \\
\text { llions) }\end{array}$ & $\begin{array}{c}\text { Own } \\
\text { tranche }\end{array}$ & $\begin{array}{l}\text { Cut-off } \\
\text { price } \\
\text { (in \%) }\end{array}$ \\
\hline 120 & 12.01 .1998 & 08.01 .2008 & 4.25 & Yes & 868 & $1^{\prime} 938.500$ & 18.945 & 0 & 105.30 \\
\hline 121 & 12.01 .1998 & 05.06 .2017 & 4.25 & Yes & 89 & 205.5 & 10.095 & 200 & 101.10 \\
\hline 122 & 11.02 .1998 & 07.10 .2004 & 4.50 & Yes & 507 & 1‘197.000 & 6.305 & 200 & 111.60 \\
\hline 123 & 11.02 .1998 & 11.02.2009 & 3.25 & No & 938 & $1^{\prime} 727.600$ & 55.742 & 300 & 101.15 \\
\hline 124 & 11.02 .1998 & 11.02 .2023 & 4.00 & No & 231 & 329.05 & 17.42 & 200 & 99.75 \\
\hline 125 & 08.04 .1998 & 08.04 .2028 & 4.00 & No & 467 & 751.5 & 18.5 & 200 & 97.75 \\
\hline 126 & 08.04 .1998 & 07.08 .2010 & 3.50 & Yes & 522 & $1^{`} 018.500$ & 16.025 & 300 & 103.80 \\
\hline 127 & 05.06 .1998 & 11.02.2009 & 3.25 & Yes & 840 & $1^{\prime} 720.600$ & 62.27 & 300 & 101.10 \\
\hline 128 & 05.06.1998 & 05.06 .2017 & 4.25 & Yes & 129 & 484 & 11.805 & 300 & 106.00 \\
\hline 129 & 07.08.1998 & 07.08 .2010 & 3.50 & Yes & 481 & 889.2 & 19.51 & 0 & 101.30 \\
\hline 130 & 07.10 .1998 & 08.04 .2028 & 4.00 & Yes & 170 & 339.1 & 0.67 & 300 & 100.25 \\
\hline 131 & 06.01 .1999 & 06.01 .2049 & 4.00 & No & 189 & 258 & 7.793 & 200 & 98.00 \\
\hline 132 & 11.02.1999 & 07.08 .2010 & 3.50 & Yes & 752 & $2 ‘ 521.020$ & 29.36 & 300 & 108.50 \\
\hline 133 & 08.04.1999 & 11.02 .2009 & 3.25 & Yes & 847 & $2^{‘} 184.605$ & 28.535 & 200 & 107.35 \\
\hline 134 & 10.06 .1999 & 10.06 .2012 & 2.75 & No & 569 & 802.2 & 25.4 & 300 & 98.50 \\
\hline 135 & 10.06 .1999 & 08.04 .2028 & 4.00 & Yes & 177 & 181.5 & 2.1 & 300 & 103.10 \\
\hline 136 & 10.06.1999 & 08.04 .2006 & 4.50 & Yes & 398 & 414.02 & 9.145 & 300 & 114.70 \\
\hline 137 & 11.08 .1999 & 11.02 .2009 & 3.25 & Yes & 287 & 541.5 & 12.88 & 300 & 103.30 \\
\hline 138 & 11.08 .1999 & 10.06 .2012 & 2.75 & Yes & 266 & 356 & 6.01 & 300 & 95.75 \\
\hline 139 & 06.10 .1999 & 11.02 .2009 & 3.25 & Yes & 479 & 565.6 & 5.14 & 300 & 99.65 \\
\hline 140 & 06.10 .1999 & 06.01 .2014 & 4.25 & Yes & 145 & 170.2 & 0.2 & 300 & 106.00 \\
\hline 141 & 17.01 .2000 & 07.08 .2010 & 3.50 & Yes & 964 & $1 ‘ 627.500$ & 10.11 & 300 & 99.60 \\
\hline 142 & 17.01 .2000 & 05.06 .2017 & 4.25 & Yes & 0 & 482.576 & 53.441 & 300 & - \\
\hline 143 & 11.02 .2000 & 11.02 .2013 & 4.00 & No & 586 & 801 & 24.23 & 300 & 100.60 \\
\hline 144 & 13.03 .2000 & 10.06 .2007 & 4.50 & Yes & 143 & 308 & 1.635 & 300 & 105.80 \\
\hline 145 & 13.03 .2000 & 07.08 .2010 & 3.50 & Yes & 768 & $1^{`} 041.000$ & 13.25 & 200 & 97.60 \\
\hline 146 & 05.04 .2000 & 11.02 .2013 & 4.00 & Yes & 899 & $1 ‘ 497.150$ & 32.175 & 300 & 99.10 \\
\hline 147 & 10.05 .2000 & 11.02 .2009 & 3.25 & Yes & 723 & $1^{`} 070.500$ & 11.41 & 300 & 94.45 \\
\hline 148 & 10.05 .2000 & 08.04 .2028 & 4.00 & Yes & 147 & 243.5 & 0.1 & 300 & 92.50 \\
\hline 149 & 13.06 .2000 & 05.06 .2017 & 4.25 & Yes & 175 & 202.75 & 0 & 300 & 98.50 \\
\hline 150 & 13.06 .2000 & 10.06 .2011 & 4.00 & No & $1 ‘ 332.000$ & $2^{`} 030.800$ & 30.52 & 300 & 98.50 \\
\hline 151 & 17.07 .2000 & 11.02 .2013 & 4.00 & Yes & 778 & $1^{‘} 009.600$ & 9.94 & 300 & 98.70 \\
\hline 152 & 07.08 .2000 & 10.06 .2012 & 2.75 & Yes & 878 & $1 ‘ 430.750$ & 8.02 & 300 & 88.50 \\
\hline 153 & 06.09 .2000 & 06.01 .2014 & 4.25 & Yes & 678 & $1 ‘ 501.650$ & 12.775 & 0 & 101.70 \\
\hline 154 & 11.10 .2000 & 10.06 .2011 & 4.00 & Yes & 744 & $1^{\prime} 703.720$ & 41.02 & 300 & 100.10 \\
\hline 155 & 08.11 .2000 & 06.01 .2014 & 4.25 & Yes & 493 & 931.6 & 2.09 & 0 & 102.40 \\
\hline 156 & 22.11 .2000 & 10.06 .2011 & 4.00 & Yes & $1 ‘ 303.000$ & $2 ‘ 533.450$ & 45.81 & 300 & 101.30 \\
\hline 157 & 22.11 .2000 & 05.06 .2017 & 4.25 & Yes & 163 & 323.55 & 2.5 & 300 & 102.60 \\
\hline 158 & 12.02 .2001 & 11.02 .2013 & 4.00 & Yes & 547 & $1^{`} 037.600$ & 4.808 & 0 & 103.40 \\
\hline 159 & 12.02 .2001 & 11.02 .2013 & 4.00 & Yes & 84 & 169.1 & 2.2 & 300 & 100.50 \\
\hline 160 & 07.03.2001 & 10.06 .2011 & 4.00 & Yes & $1^{\prime} 029.000$ & $1 ` 482.660$ & 7.425 & 0 & 104.50 \\
\hline
\end{tabular}




\begin{tabular}{|c|c|c|c|c|c|c|c|c|c|}
\hline No.* & Value date & Amortisation & $\begin{array}{l}\text { Coupon } \\
\text { (in \%) }\end{array}$ & $\begin{array}{l}\text { Reopen- } \\
\text { ing? } \\
(\mathrm{Y} / \mathrm{N})\end{array}$ & $\begin{array}{l}\text { Auction } \\
\text { size }\end{array}$ & $\begin{array}{l}\text { Competitive } \\
\text { bid } \\
\text { (in } \mathrm{CHF} \text { mi }\end{array}$ & $\begin{array}{l}\text { Non-com- } \\
\text { petitive bid } \\
\text { llions) }\end{array}$ & $\begin{array}{c}\text { Own } \\
\text { tranche }\end{array}$ & $\begin{array}{l}\begin{array}{c}\text { Cut-off } \\
\text { price }\end{array} \\
\text { (in } \%)\end{array}$ \\
\hline 161 & 09.04.2001 & 08.04 .2006 & 4.50 & Yes & 188.005 & 548.05 & 4.955 & 0 & 106.70 \\
\hline 162 & 09.05.2001 & 11.02 .2013 & 4.00 & Yes & 730.77 & $1 ‘ 147.690$ & 3.08 & 0 & 104.00 \\
\hline 163 & 11.06 .2001 & 10.06 .2015 & 3.75 & No & 524.4 & 862.3 & 6.1 & 300 & 99.90 \\
\hline 164 & 09.07.2001 & 08.04 .2028 & 4.00 & Yes & 562.225 & 767.3 & 0.425 & 300 & 99.50 \\
\hline 165 & 07.08 .2001 & 07.08 .2010 & 3.50 & Yes & 727.47 & $1^{`} 456.700$ & 8.77 & 300 & 101.35 \\
\hline 166 & 05.09 .2001 & 05.06 .2017 & 4.25 & Yes & 465.69 & 644.76 & 1.13 & 0 & 108.00 \\
\hline 167 & 08.10 .2001 & 10.06 .2015 & 3.75 & Yes & 375.05 & 403 & 2.05 & 200 & 102.60 \\
\hline 168 & 08.10 .2001 & 11.02 .2023 & 4.00 & Yes & 670.55 & 905 & 0.55 & 0 & 102.90 \\
\hline 169 & 07.11 .2001 & 10.06 .2007 & 4.50 & Yes & 109.885 & 177.4 & 4.485 & 0 & 108.90 \\
\hline 170 & 07.01 .2002 & 10.06 .2012 & 2.75 & Yes & 676.865 & $1^{\prime} 226.875$ & 10 & 0 & 95.90 \\
\hline 171 & 07.01 .2002 & 08.04 .2028 & 4.00 & Yes & 123.08 & 167.1 & 1.03 & 300 & 103.10 \\
\hline 172 & 05.02 .2002 & 10.06 .2012 & 2.75 & Yes & 880.95 & $1^{\prime} 135.950$ & 1 & 300 & 93.85 \\
\hline 173 & 05.02 .2002 & 05.06 .2017 & 4.25 & Yes & 498.39 & 537.38 & 1.01 & 300 & 106.60 \\
\hline 174 & 13.03 .2002 & 10.06 .2011 & 4.00 & Yes & 1‘191.190 & $1 ‘ 352.550$ & 1.64 & 300 & 103.75 \\
\hline 175 & 10.04 .2002 & 06.01 .2014 & 4.25 & Yes & 237.39 & 325.035 & 9.355 & 300 & 104.75 \\
\hline 176 & 08.05 .2002 & 11.02 .2009 & 3.25 & Yes & $1 ‘ 553.470$ & $1 ‘ 605.400$ & 3.07 & 300 & 99.90 \\
\hline 177 & 08.05 .2002 & 11.02 .2013 & 4.00 & Yes & 302.55 & 298.5 & 4.05 & 0 & 103.90 \\
\hline 178 & 10.06 .2002 & 10.06 .2007 & 4.50 & Yes & 884.25 & $1 ‘ 961.200$ & 8.05 & 300 & 107.75 \\
\hline 179 & 10.06 .2002 & 10.06 .2015 & 3.75 & Yes & 508 & 694 & 7 & 300 & 101.65 \\
\hline 180 & 08.07 .2002 & 11.02 .2013 & 4.00 & Yes & 364.105 & 415.05 & 1.055 & 300 & 102.25 \\
\hline 181 & 07.08 .2002 & 08.04 .2028 & 4.00 & Yes & 315.25 & 413.25 & 0 & 300 & 105.90 \\
\hline 182 & 11.09 .2002 & 05.06 .2017 & 4.25 & Yes & 128.89 & 207.39 & 3.4 & 300 & 107.10 \\
\hline 183 & 09.10 .2002 & 10.06 .2012 & 2.75 & Yes & 256.842 & 382.49 & 8.352 & 300 & 100.75 \\
\hline 184 & 06.11 .2002 & 10.06 .2011 & 4.00 & Yes & 443.615 & 598.1 & 3.525 & 300 & 109.80 \\
\hline 185 & 08.01 .2003 & 08.01 .2008 & 4.25 & Yes & 132.08 & 280 & 1.08 & 300 & 110.60 \\
\hline 186 & 08.01 .2003 & 10.06 .2012 & 2.75 & Yes & 560.58 & 692.53 & 11.05 & 0 & 101.30 \\
\hline 187 & 08.01 .2003 & 08.01 .2018 & 3.00 & No & 1‘139.190 & $1 ‘ 374.400$ & 7.09 & 300 & 98.70 \\
\hline 188 & 11.02 .2003 & 10.06 .2012 & 2.75 & Yes & 528 & 724.95 & 21.05 & 300 & 104.05 \\
\hline 189 & 11.02 .2003 & 08.01 .2018 & 3.00 & No & 710 & 806 & 23 & 0 & 102.90 \\
\hline 190 & 12.03 .2003 & 12.03 .2016 & 2.50 & No & 714.6 & 881.995 & 15.105 & 300 & 99.50 \\
\hline 191 & 08.04 .2003 & 11.02 .2013 & 4.00 & Yes & 517.08 & 658.6 & 10.48 & 300 & 112.10 \\
\hline 192 & 08.04 .2003 & 08.04 .2033 & 3.50 & No & 486.01 & 581.01 & 5 & 300 & 95.00 \\
\hline 193 & 07.05 .2003 & 12.03 .2016 & 2.50 & Yes & 461.63 & 517.48 & 13.15 & 0 & 96.10 \\
\hline 194 & 07.05 .2003 & 11.02 .2023 & 4.00 & Yes & 304.5 & 320 & 0.5 & 300 & 109.50 \\
\hline 195 & 10.06 .2003 & 10.06 .2012 & 2.75 & Yes & 268.83 & 523.3 & 7.53 & 0 & 104.40 \\
\hline 196 & 10.06 .2003 & 05.06 .2017 & 4.25 & Yes & 718.27 & 867.74 & 7.53 & 300 & 117.20 \\
\hline 197 & 09.07 .2003 & 12.03 .2016 & 2.50 & Yes & 431.68 & 782.03 & 24.1 & 300 & 97.50 \\
\hline 198 & 09.07 .2003 & 08.04 .2033 & 3.50 & Yes & $1^{\prime} 021.000$ & $1 ‘ 580.900$ & 20.6 & 300 & 100.50 \\
\hline 199 & 09.07 .2003 & 06.01 .2049 & 4.00 & Yes & 272.4 & 271.4 & 5 & 300 & 106.10 \\
\hline 200 & 06.08 .2003 & 11.02 .2023 & 4.00 & Yes & 522.67 & 696.92 & 4.05 & 0 & 111.05 \\
\hline 201 & 10.09 .2003 & 08.04 .2033 & 3.50 & Yes & 60.734 & 101.2 & 25.034 & 0 & 97.50 \\
\hline
\end{tabular}




\begin{tabular}{|c|c|c|c|c|c|c|c|c|c|}
\hline No.* & Value date & Amortisation & $\begin{array}{l}\text { Coupon } \\
\text { (in \%) }\end{array}$ & $\begin{array}{l}\text { Reopen- } \\
\text { ing? } \\
(\mathrm{Y} / \mathrm{N})\end{array}$ & $\begin{array}{l}\text { Auction } \\
\text { size }\end{array}$ & $\begin{array}{c}\text { Competitive } \\
\text { bid } \\
\text { (in } \mathrm{CHF} \text { m }\end{array}$ & $\begin{array}{l}\text { Non-com- } \\
\text { petitive bid } \\
\text { llions) }\end{array}$ & $\begin{array}{c}\text { Own } \\
\text { tranche }\end{array}$ & $\begin{array}{l}\begin{array}{c}\text { Cut-off } \\
\text { price }\end{array} \\
\text { (in \%) }\end{array}$ \\
\hline 202 & 08.10 .2003 & 10.06 .2012 & 2.75 & Yes & 617.946 & 693.55 & 17.446 & 300 & 101.00 \\
\hline 203 & 05.11 .2003 & 07.08 .2010 & 3.50 & Yes & 605.975 & 988.95 & 5.025 & 300 & 107.30 \\
\hline 204 & 05.11 .2003 & 12.03 .2016 & 2.50 & Yes & $1^{\prime} 006.000$ & $1 ‘ 698.500$ & 1 & 0 & 95.25 \\
\hline 205 & 08.01 .2004 & 08.01 .2018 & 2.75 & Yes & 236.4 & 758.2 & 3.2 & 0 & 100.20 \\
\hline 206 & 08.01 .2004 & 10.06 .2012 & 3.00 & Yes & 842.59 & $1 ‘ 353.550$ & 6.04 & 300 & 98.00 \\
\hline 207 & 11.02 .2004 & 08.01 .2008 & 4.25 & Yes & 576.175 & 757.6 & 26.575 & 0 & 110.65 \\
\hline 208 & 11.02 .2004 & 08.01 .2018 & 3.00 & Yes & 307.17 & 480.09 & 4.08 & 0 & 100.00 \\
\hline 209 & 11.02 .2004 & 11.02 .2023 & 4.00 & Yes & 201.55 & 263 & 1.55 & 300 & 110.10 \\
\hline 210 & 12.03 .2004 & 11.02 .2009 & 3.25 & Yes & 555.29 & 603.75 & 8.54 & 300 & 107.30 \\
\hline 211 & 12.03 .2004 & 12.03 .2016 & 2.50 & Yes & 643.03 & 772.03 & 8 & 300 & 96.60 \\
\hline 212 & 13.04 .2004 & 11.02 .2013 & 4.00 & Yes & 310.91 & 463.21 & 3.1 & 300 & 113.15 \\
\hline 213 & 13.04 .2004 & 08.04 .2028 & 4.00 & Yes & 886.5 & $1^{`} 040.750$ & 1.5 & 300 & 110.80 \\
\hline 214 & 12.05 .2004 & 07.08 .2010 & 3.50 & Yes & 722.12 & 765 & 7.12 & 0 & 107.05 \\
\hline 215 & 12.05 .2004 & 12.05 .2019 & 3.00 & No & 309.22 & 660.95 & 3.07 & 300 & 99.25 \\
\hline 216 & 12.05 .2004 & 08.04 .2033 & 3.50 & Yes & 230.256 & 262.206 & 1.05 & 0 & 101.50 \\
\hline 217 & 10.06 .2004 & 10.06 .2011 & 4.00 & Yes & 139.55 & 128.55 & 21 & 0 & 109.60 \\
\hline 218 & 10.06 .2004 & 10.06 .2015 & 3.75 & Yes & 276.7 & 271.2 & 16.5 & 300 & 107.65 \\
\hline 219 & 10.06 .2004 & 11.02 .2023 & 4.00 & Yes & 182.6 & 186.6 & 1 & 0 & 109.25 \\
\hline 220 & 07.07.2004 & 10.06 .2012 & 2.75 & Yes & 327.24 & 378.49 & 4.75 & 300 & 100.10 \\
\hline 221 & 07.07 .2004 & 12.03 .2016 & 2.50 & Yes & 394.905 & 432.905 & 8 & 0 & 94.55 \\
\hline 222 & 07.07 .2004 & 08.04 .2028 & 4.00 & Yes & 94.6 & 122.6 & 0 & 0 & 107.70 \\
\hline 223 & 09.08 .2004 & 07.08 .2010 & 3.50 & Yes & 598.845 & 689.75 & 7.095 & 300 & 105.70 \\
\hline 224 & 09.08.2004 & 06.01 .2014 & 4.25 & Yes & 619.04 & 779.7 & 1.34 & 300 & 111.00 \\
\hline 225 & 08.09 .2004 & 10.06 .2012 & 2.75 & Yes & 293.45 & 351.05 & 4.4 & 0 & 101.45 \\
\hline 226 & 08.09 .2004 & 12.03 .2016 & 2.50 & Yes & 276.56 & 337.53 & 4.03 & 0 & 95.95 \\
\hline 227 & 07.10 .2004 & 11.02 .2013 & 4.00 & Yes & 708.85 & $1^{`} 031.350$ & 2.5 & 300 & 110.95 \\
\hline 228 & 07.10 .2004 & 12.05 .2019 & 3.00 & Yes & 696.67 & $1^{`} 027.900$ & 33.57 & 0 & 99.80 \\
\hline 229 & 05.11 .2004 & 05.11 .2009 & 1.75 & No & 627.82 & $1 ‘ 963.390$ & 31.18 & 300 & 99.90 \\
\hline 230 & 06.01 .2005 & 05.11 .2009 & 1.75 & Yes & 421.19 & 754.7 & 16.24 & 0 & 100.05 \\
\hline 231 & 06.01 .2005 & 12.05 .2019 & 3.00 & Yes & 1'228.105 & 1‘966.080 & 36.025 & 0 & 104.15 \\
\hline 232 & 09.02 .2005 & 05.11 .2009 & 1.75 & Yes & 406.675 & 450.875 & 40.8 & 0 & 101.00 \\
\hline 233 & 09.03 .2005 & 08.01 .2018 & 3.00 & Yes & 345.335 & 326.325 & 58.01 & 0 & 105.85 \\
\hline 234 & 06.04 .2005 & 12.03 .2016 & 2.50 & Yes & 356.945 & 422.945 & 14.6 & 0 & 100.30 \\
\hline 235 & 11.05 .2005 & 08.01 .2018 & 3.00 & Yes & 301.1 & 516.14 & 8.96 & 0 & 108.20 \\
\hline 236 & 08.06 .2005 & 12.03 .2016 & 2.50 & Yes & 519.187 & 773.987 & 9.2 & 0 & 104.45 \\
\hline 237 & 06.07 .2005 & 06.07 .2020 & 2.25 & No & 422.6 & 682.49 & 41.81 & 300 & 100.50 \\
\hline 238 & 07.09 .2005 & 06.07 .2020 & 2.25 & Yes & 366.92 & 498.92 & 13 & 0 & 101.20 \\
\hline 239 & 12.10 .2005 & 12.10 .2016 & 2.00 & No & 482.87 & 435 & 60.87 & 300 & 100.05 \\
\hline 240 & 09.11 .2005 & 09.11 .2014 & 2.00 & No & 547.17 & $1^{‘} 099.300$ & 51.87 & 300 & 99.80 \\
\hline 241 & 09.11 .2005 & 06.07 .2020 & 2.25 & Yes & 160.72 & 235.62 & 18.5 & 0 & 100.70 \\
\hline 242 & 04.01 .2006 & 09.11 .2014 & 2.00 & Yes & 304.96 & 426.51 & 9.45 & 0 & 98.75 \\
\hline
\end{tabular}




\begin{tabular}{|c|c|c|c|c|c|c|c|c|c|}
\hline No.* & Value date & Amortisation & $\begin{array}{l}\text { Coupon } \\
\text { (in \%) }\end{array}$ & $\begin{array}{l}\text { Reopen- } \\
\text { ing? } \\
(\mathrm{Y} / \mathrm{N})\end{array}$ & $\begin{array}{l}\text { Auction } \\
\text { size }\end{array}$ & $\begin{array}{l}\text { Competitive } \\
\text { bid } \\
\text { (in } \mathrm{CHF} \text { mi }\end{array}$ & $\begin{array}{l}\text { Non-com- } \\
\text { petitive bid } \\
\text { llions) }\end{array}$ & $\begin{array}{c}\text { Own } \\
\text { tranche }\end{array}$ & $\begin{array}{c}\text { Cut-off } \\
\text { price } \\
\text { (in \%) }\end{array}$ \\
\hline 243 & 04.01 .2006 & 06.07 .2020 & 2.25 & Yes & 226.06 & 286.06 & 0 & 0 & 98.60 \\
\hline 244 & 08.02 .2006 & 10.06 .2015 & 3.75 & Yes & 569.12 & 774.02 & 35.1 & 300 & 113.70 \\
\hline 245 & 08.03 .2006 & 12.10 .2016 & 2.00 & Yes & 448.81 & 678.66 & 50.15 & 0 & 97.95 \\
\hline 246 & 08.03 .2006 & 08.03 .2036 & 2.50 & No & 222.45 & 323.06 & 3.9 & 300 & 102.10 \\
\hline 247 & 10.04 .2006 & 09.11 .2014 & 2.00 & Yes & 754.21 & 920.21 & 13 & 0 & 97.30 \\
\hline 248 & 10.05 .2006 & 12.03 .2016 & 2.50 & Yes & 453.35 & 672.85 & 21.2 & 300 & 98.20 \\
\hline 249 & 07.06 .2006 & 12.05 .2019 & 3.00 & Yes & 678.09 & 904.09 & 6 & 0 & 101.55 \\
\hline 250 & 12.07 .2006 & 08.03 .2036 & 2.50 & Yes & 180.755 & 656.755 & 2 & 0 & 90.00 \\
\hline 251 & 09.08.2006 & 06.07 .2020 & 2.25 & Yes & 246.29 & 485.55 & 26.74 & 0 & 92.40 \\
\hline 252 & 06.09 .2006 & 12.05 .2019 & 3.00 & Yes & 213.32 & 445.56 & 20.56 & 0 & 103.90 \\
\hline 253 & 11.10 .2006 & 08.03 .2036 & 2.50 & Yes & 81.3 & 128.725 & 2 & 0 & 100.00 \\
\hline 254 & 08.11 .2006 & 12.10 .2016 & 2.00 & Yes & 357.99 & 387.59 & 16.4 & 0 & 95.00 \\
\hline 255 & 05.01 .2007 & 06.07 .2020 & 2.25 & Yes & 495.5 & 626.06 & 1 & 0 & 98.50 \\
\hline 256 & 24.01 .2007 & 12.10 .2016 & 2.00 & Yes & 535.78 & 744.78 & 7 & 0 & 94.65 \\
\hline 257 & 27.02.2007 & 08.01 .2018 & 3.00 & Yes & 395.017 & 503.417 & 11.6 & 300 & 102.90 \\
\hline 258 & 28.03 .2007 & 12.05 .2019 & 3.00 & Yes & 494.88 & 661.28 & 14.1 & 0 & 103.20 \\
\hline 259 & 25.04 .2007 & 12.10 .2016 & 2.00 & Yes & 447.03 & 473.93 & 78.1 & 0 & 93.75 \\
\hline 260 & 05.06 .2007 & 05.06 .2017 & 4.25 & Yes & 664.82 & 881.8 & 3.02 & 300 & 111.65 \\
\hline 261 & 27.06.2007 & 27.06 .2027 & 3.25 & No & 100.65 & 341.65 & 10 & 300 & 97.50 \\
\hline 262 & 25.07.2007 & 12.05 .2019 & 3.00 & Yes & 437.56 & 801.51 & 32.55 & 300 & 96.20 \\
\hline 263 & 26.09.2007 & 08.04 .2028 & 4.00 & Yes & 69.8 & 127.25 & 40.55 & 300 & 113.25 \\
\hline 264 & 24.10 .2007 & 08.04 .2033 & 3.50 & Yes & 56.7 & 112.2 & 5.6 & 300 & 103.35 \\
\hline 265 & 08.01 .2008 & 08.01 .2018 & 3.00 & Yes & 433.265 & 452.515 & 55.75 & 0 & 99.80 \\
\hline 266 & 08.01 .2008 & 12.03 .2016 & 2.50 & Yes & 445.96 & 552.7 & 8.26 & 0 & 96.40 \\
\hline 267 & 23.01 .2008 & 12.05 .2019 & 3.00 & Yes & 308.1 & 838.4 & 69.7 & 0 & 99.80 \\
\hline 268 & 27.02.2008 & 11.02 .2023 & 4.00 & Yes & 296.675 & 470.1 & 5.175 & 300 & 109.70 \\
\hline 269 & 26.03 .2008 & 27.06.2027 & 3.25 & Yes & 122.74 & 303.61 & 9.13 & 0 & 98.00 \\
\hline 270 & 23.04 .2008 & 08.04 .2033 & 3.50 & Yes & 150.32 & 246.6 & 15.72 & 0 & 100.80 \\
\hline 271 & 08.01 .2009 & 08.01 .2018 & 3.00 & Yes & 622.14 & 841.76 & 52.38 & 0 & 102.85 \\
\hline 272 & 08.01 .2009 & 08.01 .2018 & 3.00 & Yes & 481.121 & 627.2 & 0.121 & 0 & 106.00 \\
\hline 273 & 11.02 .2009 & 06.07 .2020 & 2.25 & Yes & 222.66 & 536.15 & 55.51 & 300 & 98.60 \\
\hline 274 & 25.02 .2009 & 08.01 .2018 & 3.00 & Yes & 559.04 & $1^{`} 361.650$ & 29.39 & 0 & 107.90 \\
\hline 275 & 25.03 .2009 & 08.03 .2036 & 2.50 & Yes & 163.2 & 638.675 & 5.525 & 300 & 101.35 \\
\hline 276 & 22.04 .2009 & 12.10 .2016 & 2.00 & Yes & 394.3 & 579.3 & 46 & 0 & 100.40 \\
\hline 277 & 27.05.2009 & 12.05 .2019 & 3.00 & Yes & 232.689 & 875.399 & 54.54 & 0 & 105.60 \\
\hline 278 & 06.07.2009 & 06.07 .2020 & 2.25 & Yes & 247.71 & 690.25 & 49.71 & 0 & 96.60 \\
\hline 279 & 01.02 .2010 & 06.07 .2020 & 2.25 & Yes & 646.4 & $1^{`} 246.760$ & 50.69 & 0 & 101.70 \\
\hline 280 & 24.02 .2010 & 27.06 .2027 & 3.25 & Yes & 189.6 & 959.2 & 18 & 0 & 116.00 \\
\hline 281 & 24.03 .2010 & 08.03 .2036 & 2.50 & Yes & 117.1 & 111 & 6.1 & 0 & 104.00 \\
\hline 282 & 28.04 .2010 & 28.04 .2021 & 2.00 & No & 674.75 & 997.95 & 60.55 & 300 & 100.00 \\
\hline 283 & 26.05 .2010 & 28.04.2021 & 2.00 & Yes & 224.323 & 469.123 & 16 & 0 & 101.75 \\
\hline
\end{tabular}




\begin{tabular}{|c|c|c|c|c|c|c|c|c|c|}
\hline No.* & Value date & Amortisation & $\begin{array}{l}\text { Coupon } \\
\text { (in \%) }\end{array}$ & $\begin{array}{l}\text { Reopen- } \\
\text { ing? } \\
(\mathrm{Y} / \mathrm{N})\end{array}$ & $\begin{array}{l}\text { Auction } \\
\text { size }\end{array}$ & $\begin{array}{c}\text { Competitive } \\
\text { bid } \\
\text { (in CHF m }\end{array}$ & $\begin{array}{l}\text { Non-com- } \\
\text { petitive bid } \\
\text { llions) }\end{array}$ & $\begin{array}{c}\text { Own } \\
\text { tranche }\end{array}$ & $\begin{array}{l}\begin{array}{c}\text { Cut-off } \\
\text { price }\end{array} \\
\text { (in \%) }\end{array}$ \\
\hline 284 & 23.06 .2010 & 12.05 .2019 & 3.00 & Yes & 800.46 & 820.01 & 16.45 & 0 & 113.25 \\
\hline 285 & 22.09 .2010 & 28.04 .2021 & 2.00 & Yes & 445.1 & 462.575 & 59.7 & 0 & 105.50 \\
\hline 286 & 27.10 .2010 & 28.04 .2021 & 2.00 & Yes & 412.608 & 606.408 & 2.2 & 0 & 105.10 \\
\hline 287 & 27.10 .2010 & 08.03 .2036 & 2.50 & Yes & 270.5 & 865.5 & 2 & 300 & 117.40 \\
\hline 288 & 05.01 .2011 & 27.06 .2027 & 3.25 & No & 625.5 & 821.2 & 6.3 & 0 & 121.80 \\
\hline 289 & 05.01 .2011 & 28.04 .2021 & 2.00 & No & 729.1 & 900.75 & 6.85 & 0 & 102.35 \\
\hline 290 & 26.01 .2011 & 06.07 .2020 & 2.25 & No & 431.51 & 967.66 & 9.85 & 0 & 104.65 \\
\hline 291 & 23.02 .2011 & 28.04 .2021 & 2.00 & Yes & 334.9 & 495.4 & 11.5 & 0 & 100.40 \\
\hline 292 & 23.02 .2011 & 08.04 .2033 & 3.50 & No & 427.64 & 746.64 & 5 & 300 & 122.05 \\
\hline 293 & 23.03 .2011 & 08.03 .2036 & 2.50 & No & 465.63 & 467.56 & 7.07 & 0 & 105.75 \\
\hline 294 & 28.04 .2011 & 28.04 .2021 & 2.00 & Yes & 313.7 & 796.4 & 2 & 0 & 98.85 \\
\hline 295 & 25.05 .2011 & 25.05 .2022 & 2.00 & No & 530.625 & 816.925 & 13.2 & 300 & 100.10 \\
\hline 296 & 22.06 .2011 & 22.06 .2031 & 2.25 & No & 477.535 & $1 ‘ 142.120$ & 23.815 & 300 & 102.50 \\
\hline 297 & 27.07 .2011 & 25.5 .2022 & 2.00 & Yes & 434.37 & 837.47 & 51.4 & 0 & 103.90 \\
\hline 298 & 28.09 .2011 & 25.5 .2022 & 2.00 & Yes & 210.4 & 352.4 & 25 & 0 & 109.50 \\
\hline 299 & 28.09 .2011 & 06.01 .2049 & 4.00 & No & 106.57 & 114 & 16.37 & 300 & 168.50 \\
\hline 300 & 26.10 .2011 & 22.06 .2031 & 2.25 & Yes & 165.93 & 235.5 & 12.93 & 0 & 115.50 \\
\hline 301 & 05.01 .2012 & 27.06 .2027 & 3.25 & Yes & 240.45 & 266.45 & 1 & 300 & 127.90 \\
\hline 302 & 05.01 .2012 & 25.05 .2022 & 2.00 & Yes & 392.842 & 511.842 & 18 & 0 & 111.75 \\
\hline 303 & 05.01 .2012 & 22.06 .2031 & 2.25 & Yes & 244.65 & 334.65 & 6 & 0 & 120.25 \\
\hline 304 & 25.01 .2012 & 27.06 .2027 & 3.25 & Yes & 150 & 186.15 & 5 & 0 & 130.40 \\
\hline 305 & 22.02 .2012 & 25.05 .2022 & 2.00 & Yes & 671.3 & 721.7 & 11.6 & 0 & 111.60 \\
\hline 306 & 22.02 .2012 & 22.06 .2031 & 2.25 & Yes & 430.25 & 465.25 & 2 & 0 & 119.10 \\
\hline 307 & 28.03 .2012 & 06.07 .2020 & 2.25 & Yes & 634.5 & 617 & 32.5 & 0 & 112.75 \\
\hline 308 & 28.03 .2012 & 08.03 .2036 & 2.50 & Yes & 299.485 & 347.15 & 4.835 & 300 & 127.05 \\
\hline 309 & 30.04 .2012 & 28.04 .2021 & 2.00 & Yes & 177.38 & 679.85 & 15.03 & 0 & 111.25 \\
\hline 310 & 30.04 .2012 & 30.04 .2042 & 1.50 & No & 872.305 & $1^{`} 012.800$ & 6.505 & 300 & 108.35 \\
\hline 311 & 11.06 .2012 & 11.06 .2024 & 1.25 & No & 216.39 & 639.92 & 30.69 & 300 & 105.50 \\
\hline 312 & 11.06 .2012 & 30.04 .2042 & 1.50 & Yes & 361.93 & 638.76 & 3.17 & 300 & 111.60 \\
\hline 313 & 27.06 .2012 & 27.06 .2037 & 1.25 & No & 267.17 & 645.1 & 21.57 & 300 & 107.25 \\
\hline 314 & 25.07 .2012 & 11.06 .2024 & 1.25 & Yes & 153.16 & 379.76 & 17.3 & 0 & 106.75 \\
\hline 315 & 25.07 .2012 & 27.06 .2037 & 1.25 & Yes & 422.774 & 423.2 & 5.574 & 0 & 105.25 \\
\hline 316 & 26.09 .2012 & 10.06 .2015 & 3.75 & No & 656 & $1 ‘ 638.000$ & 5 & 0 & 110.75 \\
\hline 317 & 26.09 .2012 & 11.06 .2024 & 1.25 & Yes & 277.5 & 580 & 5.5 & 0 & 105.25 \\
\hline 318 & 24.10 .2012 & 27.06 .2037 & 1.25 & Yes & 329.79 & $1 ‘ 326.400$ & 13.39 & 0 & 104.75 \\
\hline 319 & 07.01 .2013 & 30.04 .2042 & 1.50 & Yes & 836.4 & 1927.27 & 14.38 & 0 & 113.20 \\
\hline 320 & 07.01 .2013 & 27.06 .2037 & 1.25 & Yes & 298.95 & 336.425 & 5.025 & 300 & 106.10 \\
\hline 321 & 23.01 .2013 & 10.06 .2015 & 3.75 & Yes & 230 & 553 & 0 & 0 & 109.35 \\
\hline 322 & 23.01 .2013 & 11.06 .2024 & 1.25 & Yes & 423.1 & 665.1 & 5 & 0 & 106.50 \\
\hline 323 & 27.02 .2013 & 11.06 .2024 & 1.25 & Yes & 329.55 & 451.25 & 12.3 & 0 & 103.85 \\
\hline 324 & 27.02 .2013 & 27.06 .2037 & 1.25 & Yes & 142.5 & 392.5 & 5 & 0 & 100.50 \\
\hline
\end{tabular}




\begin{tabular}{|c|c|c|c|c|c|c|c|c|c|}
\hline No.* & Value date & Amortisation & $\begin{array}{l}\text { Coupon } \\
\text { (in \%) }\end{array}$ & $\begin{array}{l}\text { Reopen- } \\
\text { ing? } \\
(\mathrm{Y} / \mathrm{N})\end{array}$ & $\begin{array}{l}\text { Auction } \\
\text { size }\end{array}$ & $\begin{array}{l}\text { Competitive } \\
\text { bid } \\
\text { (in } \mathrm{CHF} \text { mi }\end{array}$ & $\begin{array}{l}\text { Non-com- } \\
\text { petitive bid } \\
\text { llions) }\end{array}$ & $\begin{array}{c}\text { Own } \\
\text { tranche }\end{array}$ & $\begin{array}{c}\text { Cut-off } \\
\text { price } \\
\text { (in \%) }\end{array}$ \\
\hline 325 & 27.03 .2013 & 25.05 .2022 & 2.00 & Yes & 317.3 & 673.2 & 25.1 & 0 & 111.60 \\
\hline 326 & 27.03 .2013 & 30.04 .2042 & 1.50 & Yes & 113.605 & 255.31 & 3.045 & 0 & 105.90 \\
\hline 327 & 29.04 .2013 & 28.04 .2021 & 2.00 & Yes & 124.5 & 1056.5 & 18 & 0 & 111.80 \\
\hline 328 & 29.04 .2013 & 27.06 .2037 & 1.25 & Yes & 569.375 & 1636.89 & 4.045 & 0 & 101.30 \\
\hline 329 & 11.06 .2013 & 11.06 .2024 & 1.25 & Yes & 442.17 & 1224.6 & 15.07 & 300 & 105.85 \\
\hline 330 & 26.06 .2013 & 30.04 .2042 & 1.50 & Yes & 194.045 & 551 & 7.045 & 0 & 100.95 \\
\hline 331 & 24.07 .2013 & 24.07 .2025 & 1.50 & No & 539.93 & 780.93 & 23 & 300 & 102.50 \\
\hline 332 & 25.09 .2013 & 28.04 .2021 & 2.00 & Yes & 281.89 & 464.76 & 13.13 & 0 & 107.65 \\
\hline 333 & 25.09 .2013 & 08.03 .2036 & 2.50 & Yes & 502.62 & 1168.15 & 14.97 & 0 & 114.75 \\
\hline 334 & 23.10 .2013 & 24.07 .2025 & 1.50 & Yes & 222.8 & 609.2 & 20 & 0 & 102.60 \\
\hline 335 & 23.10 .2013 & 30.04 .2042 & 1.50 & Yes & 467.05 & 724.8 & 8 & 0 & 97.25 \\
\hline 336 & 06.01 .2014 & 11.06 .2024 & 1.25 & Yes & 242.06 & 381 & 11.06 & 0 & 100.60 \\
\hline 337 & 06.01 .2014 & 27.06 .2037 & 1.25 & Yes & 149.28 & 184.7 & 4.58 & 0 & 92.00 \\
\hline 338 & 22.01 .2014 & 24.07 .2025 & 1.50 & Yes & 589.92 & 629.65 & 20.27 & 0 & 101.50 \\
\hline 339 & 22.01 .2014 & 30.04 .2042 & 1.50 & Yes & 76.51 & 211.32 & 3.51 & 0 & 96.00 \\
\hline 340 & 26.02 .2014 & 11.06 .2024 & 1.25 & Yes & 141.615 & 352.1 & 9.515 & 0 & 101.95 \\
\hline 341 & 26.02.2014 & 06.01 .2049 & 4.00 & Yes & 135.845 & 190.1 & 3.695 & 0 & 161.10 \\
\hline 342 & 26.02 .2014 & 28.04 .2021 & 2.00 & Yes & 240.2 & 571.7 & 68.5 & 0 & 109.80 \\
\hline 343 & 26.03 .2014 & 25.05 .2022 & 2.00 & Yes & 346.43 & 599.68 & 24.75 & 300 & 110.00 \\
\hline 344 & 26.03 .2014 & 22.06 .2031 & 2.25 & Yes & 222.8 & 412.8 & 6 & 0 & 112.85 \\
\hline 345 & 23.04 .2014 & 11.06 .2024 & 1.25 & Yes & 242.1 & 482.6 & 37 & 0 & 103.20 \\
\hline 346 & 23.04 .2014 & 27.06 .2037 & 1.25 & Yes & 342.1 & 429.6 & 4 & 0 & 95.25 \\
\hline 347 & 28.05 .2014 & 28.05 .2026 & 1.25 & No & 301.3 & 703.3 & 51 & 300 & 103.30 \\
\hline 348 & 25.06 .2014 & 11.06 .2024 & 1.25 & Yes & 137 & 480 & 23 & 0 & 104.50 \\
\hline 349 & 25.06 .2014 & 25.06 .2064 & 2.00 & No & 564.65 & 959.3 & 9.35 & 300 & 113.70 \\
\hline 350 & 23.07 .2014 & 28.05 .2026 & 1.25 & Yes & 213.9 & 596.7 & 17.2 & 0 & 104.55 \\
\hline 351 & 24.09 .2014 & 28.05 .2026 & 1.25 & Yes & 237.25 & 444.75 & 20.5 & 0 & 105.55 \\
\hline 352 & 24.09 .2014 & 27.06 .2037 & 1.25 & Yes & 171.75 & 379.15 & 23.6 & 0 & 100.95 \\
\hline 353 & 10.11 .2014 & 11.06 .2024 & 1.25 & Yes & 138.75 & 307.95 & 39 & 0 & 107.70 \\
\hline 354 & 10.11 .2014 & 25.06 .2064 & 2.00 & Yes & 555.05 & 1154.55 & 6.5 & 300 & 128.45 \\
\hline 355 & 26.11 .2014 & 24.07 .2025 & 1.50 & Yes & 208.834 & 459.134 & 55 & 0 & 110.55 \\
\hline 356 & 05.01 .2015 & 28.05 .2026 & 1.25 & Yes & 121 & 166.5 & 11.5 & 0 & 109.25 \\
\hline 357 & 05.01 .2015 & 27.06 .2037 & 1.25 & Yes & 167.05 & 305.95 & 7.5 & 0 & 108.75 \\
\hline
\end{tabular}

The two auctions that were cancelled are marked in yellow.

* Auction days are available upon request. 


\section{References}

Álvarez, Francisco and Cristina Mazón. 2002. Treasury Auctions: The Spanish format. Working Paper, November 13.

Anderson, Phillip. 2006. Should public debt be managed by a separate agency? In Government Debt Management: New Trends and Challenges, Mike Williams (Ed.), 79-92. Central Banking Publications.

Armantier, Olivier and Erwann Sbaï. 2006. Estimation and Comparison of Treasury Auction Formats when Bidders are Asymmetric. Journal of Applied Econometrics 21: 745-779.

Armantier, Olivier and Nourredine Lafhel. 2009. Comparison of Auction Formats in Canadian Government Auctions. Bank of Canada Working Paper 2009-5.

Arnone, Marco and George Iden. 2003. Primary Dealers in Government Securities: Policy Issues and Selected Countries' Experience. IMF Working Paper No. 03/45.

Ausubel, Lawrence M. 2004. An Efficient Ascending-Bid Auction for Multiple Objects. American Economic Review 94(5): 1452-1575.

Ausubel, Lawrence M. 2008. Auctions (theory). In The New Palgrave Dictionary of Economics. Second Edition, Eds. Steven N. Durlauf and Lawrence E. Blume. Palgrave Macmillan.

Ausubel, Lawrence M. and Peter Cramton. 2002. Demand reduction and inefficiency in multi-unit auctions. Working Paper, University of Maryland.

Ausubel, Lawrence M., Peter Cramton, Marek Pycia, Marzena Rostek, and Marek Weretka. 2013. Demand Reduction and Inefficiency in Multi-Unit Auctions, July.

Back, Kerry and Jaime F. Zender. 1993. Auctions of Divisible Goods: On the Rationale for the Treasury Experiment. Review of Financial Studies 6: 733-764.

Bartolini, Leonardo and Carlo Cottarelli. 1994. Treasury Bill Auctions: Issues and Uses. IMF Working Paper No. 94/135.

Bernhard, Roger and Enzo Rossi. 2000. Do we really need primary dealers? A note at the Tenth OECD Workshop on Government Securities Markets and Public Debt Management in Emerging Markets. Warsaw, 29-30 May.

Bikhchandani, S. and Chi-fu Huang. 1989. Auction with Resale Markets: A Model of Treasury Bill Markets. Review of Financial Studies 2: 311-339.

Bikhchandani, S. and Chi-fu Huang. 1993. The Economics of Treasury Securities Markets. Journal of Economic Perspectives 7, Summer: 117-134.

Binmore, Ken and Joseph E. Swierzbinski. 2000. Treasury auctions: Uniform or discriminatory? Review of Economic Design 5(4): 387-410.

Bischofberger, Armin. 1997. Der Handel in Eidgenössischen Anleihen. Verlag Paul Haupt, Bern, Stuttgart, Wien.

Blommestein, Hans J. and Gert Wehinger. 2007. Public Debt Management and the Evolving Market for (Ultra-)Long Government Bonds. OECD Journal: Financial Market Trends 2007/2: 201-238.

Blommestein, Hans J., Vincenzo Guzzo, Allison Holland and Yibin Mu. 2010. Debt Markets: Policy Challenges in the Post-Crisis Landscape. OECD Journal: Financial Market Trends 2010(1): 143-169.

Boesiger, Robert. 1982. Die Emission von Bundesanleihen nach dem Tenderverfahren. Hausarbeit, Universität Basel. 
Brenner, Menachem, Dan Galai, and Orly Sade. 2009. Sovereign debt auctions: Uniform or discriminatory? Journal of Monetary Economics 56: 267-274.

Bröker, Günther. 1993. Government Securities and Debt Management in the 1990s. OECD, Paris.

Bund, Der. 1992. Tenderpreis verblüfft. 143. Jahrgang Nr. 280.

Chari, V.V. and Robert J. Weber. 1992. How the U.S. Treasury Should Auction Its Debt. Federal Reserve Bank of Minneapolis Quarterly Review, Fall: 3-12.

Damianov, Damian S. and Johannes Gerd Becker. 2010. Auctions with variable supply: Uniform price versus discriminatory. European Economic Review 54: 571-593.

Daripa, Arupratan. 2001. A theory of treasury auctions. Journal of International Money and Finance 20: 743-767.

Das, Sanijv Ranjan and Rangarajan K. Sundaram. 1997. Auction Theory: A Summary with Applications to Treasury Markets. NBER Working Paper 5873.

Department of the Treasury, Securities and Exchange Commission, Board of Governors of the Federal Reserve System. 1992. Joint Report on the Government Securities Market.

Eidgenössische Finanzverwaltung. 1977. Diskussionsgrundlage zu einer eventuellen Neugestaltung der Bundesanleihen.

Federal Treasury. 2015. Acticity report 2014, March.

Feldman, Robert A. and Rajnish Mehra. 1993. Auctions. Theory and Applications. IMF Staff Paper 40(3), September: 485-511.

Finanz und Wirtschaft. 1995. Bundestresorerie überrascht. 11. Oktober.

Fortunato, Franco and Fabienne M. Megevand. 1988. Les Emprunts "Tender" de la Confédération. Mémoire de Licence. Université de Genève.

Friedman, Milton. 1959a. Testimony in Employment, Growth, and Price Levels. Hearings before the Joint Economic Committee. $86^{\text {th }}$ Congress, $1^{\text {st }}$ Session, October 30, 3032-3026.

Friedman, Milton. 1959b. A Program for Monetary Stability. The Millar Lectures number Three. Fordham University Press, New York City.

Friedman, Milton. 1991. How to sell government securities. Wall Street Journal, August 18.

Garbade, Kenneth D. 2004. The Institutionalization of Treasury Note and Bond Auctions, 1970-75. FRBNY Economic Policy Review, May: 29-45.

Garbade, Kenneth D. 2007. The Emergence of "Regular and Predictable" as a Treasury Debt Management Strategy. FRBNY Economic Policy Review, March: $53-71$.

Garbade, Kenneth D. 2008. Why the U.S. Treasury Began Auctioning Treasury Bills in 1929. FRBNY Economic Policy Review, July: 31-47.

Goldreich, David. 2007. Underpricing in Discriminatory and Uniform-Price Treasury Auctions. Journal of Financial and Quantitative Analysis 42(2), June: 443-466.

Heller, Daniel and Yvan Lengwiler. 2001. Should the Treasury Price-Discriminate? A Procedure for Computing Hypothetical Bid Functions. Journal of Institutional and Theoretical Economics 157: 413-429.

Hortaçsu, Ali. 2002. Mechanism Choice and Strategic Bidding in Divisible Good Auctions: An Empirical Analysis of the Turkish Treasury Auction Market. 
Keloharju, Matti, Kjell G. Nyborg, and Kristian Rydqvist. 2005. Strategic Behavior and Underpricing in Uniform Price Auctions: Evidence from Finnish Treasury Auctions. Journal of Finance 60(4), August: 1865-1901.

Klemperer, Paul. 1999. Auction Theory: A Guide to the Literature. Journal of Economic Surveys 13(3), July: 227-286.

Kroszner, Randall S. 1998. Global Government Securities Markets: Economics and Politics of Recent Market Microstructure Reforms. In The Debt Burden and its Consequences for Monetary Policy. Proceedings of a Conference held by the International Economic Association at the Deutsche Bundesbank, Frankfurt, Germany. Guillermo Calvo and Mervyn King (Eds), 86-110. Macmillan Press Ltd.

Kwasnica, Anthony M. and Katerina Sherstyuk. 2013. Multiunit Auctions. Journal of Economic Surveys 27(3): 461-490.

Malvey, Paul F. and Christine M. Archibald. 1998. Uniform-Price Auctions: Update of the Treasury Experience. Department of the Treasury, October.

Malvey, Paul F., Christine M. Archibald, Sean T. Flynn. 1995. Uniform-Price Auctions: Evaluation of the Treasury Experience. Washington, D.C., U.S., Treasury, October.

McAfee, R. Preston and John McMillan. 1987. Auctions and Bidding. Journal of Economic Literature 25, June: 699-738.

Milgrom, Paul, 1987. An Essay on Price Discrimination. Economics Working Papers 8732, University of California at Berkeley.

Milgrom, Paul. 1989. Auctions and Bidding: A Primer. Journal of Economic Perspectives 3(3): 3-22.

Nandi, Saikat. 1997. Treasury Auctions: What Do the Recent Models and Results Tell Us? Federal Reserve Bank of Atlanta Economic Review, Fourth Quarter: 4-15.

Neue Zürcher Zeitung. 1986. Eidgenossenschaft mit 41/4 Prozent. 8. März.

Nyborg, Kjell G. and Ilya A. Strebulaev. 2004. Multiple Unit Auctions and Short Squeezes. Review of Financial Studies 17(2): 545-580.

Nyborg, Kjell G. and Suresh Sundaresan. 1996. Discriminatory versus Uniform Treasury Auctions: Evidence from When-Issued Transactions. Journal of Financial Economics 42, September: 63-104.

OECD. 1983. Government Debt Management. Debt Instruments and Selling Techniques. Committee on Financial Markets - Group of Experts on Government Debt Management. Volume II.

OECD. 2012. OECD Sovereign Borrowing Outlook 2012.

OECD. 2013. OECD Sovereign Borrowing Outlook 2013.

Piga, Gustavo. 1998. In Search of an Independent Province for the Treasuries: How Should Public Debt Be Managed? Journal of Economics and Business 50: 257-275.

Reinhart, Vincent. 1992. An Analysis of Potential Treasury Auction Techniques. Federal Reserve Bulletin 78, June: 403-413.

SBG/UBS Schweizerische Bankgesellschaft. 1984. Das Effekten-Emissionsgeschäft in der Schweiz. SBG-Schriften zu Wirtschafts-, Bank- und Währungsfragen Nr. 93.

Schwartz, J.-J. 1980. Das neue Emissionsverfahren für Bundesanleihen. Neue Zürcher Zeitung, 7. Januar, Nr. 4.

Simon, David P. 1994. The Treasury's experiment with single-price auctions in the mid-1970s: Winner's or taxpayer's curse. Review of Economics and Statistics 76: 754-760. 
Thomann, Peter. 2002. Bundestender. In Geld-, Bank- und Finanzmarkt-Lexikon der Schweiz. M. Boemle, M. Gsell, J.-P. Jetzer, P. Nyffeler, Ch. Thalman eds., 229 f., Verlag SKV.

UBS. 2013. The CHF Fixed Income Market: A Primer. UBS Investment Research Swiss Economic Focus. 1 March 2013.

Wang, James J. D. and Jaime F. Zender. 2002. Auctioning divisible goods. Economic Theory 19: 673-705.

Wasserfallen, Walter and Daniel Wydler. 1988. Underpricing of Newly Issued Bonds: Evidence from the Swiss Capital Market. Journal of Finance 43(5): 1177-1191.

Wilson, Robert. 1977. A Bidding Model of Perfect Competition. Review of Economic Studies 44, October: 511-518.

Wolswijk, Guido and Jakob de Haan. 2005. Government debt management in the euro area - recent theoretical developments and changes in practices. Occasional Paper Series 25, European Central Bank. 

10/2016 Angelo Ranaldo and Enzo Rossi: Uniform-price auctions for Swiss government bonds:

Origin and evolution

09/2016 Severin Bernhard: A real-time GDP data set for Switzerland

08/2014 Barbara Rudolf and Mathias Zurlinden: A compact open economy DSGE model for Switzerland

07/2013 Marco Huwiler and Daniel Kaufmann: Combining disaggregate forecasts for inflation: The SNB's ARIMA model

06/2009 Katrin Assenmacher-Wesche and M. Hashem Pesaran: A VECX* model of the Swiss economy

05/2009 Nicolas Alexis Cuche-Curti, Harris Dellas and JeanMarc Natal: A dynamic stochastic general equilibrium model for Switzerland

04/2007 Jonas Stulz: Exchange rate pass-through in Switzerland: Evidence from vector autoregressions

03/2007 Ernst Baltensperger, Philipp M. Hildebrand and Thomas J. Jordan: The Swiss National Bank's monetary policy concept - an example of a 'principlesbased' policy framework

02/2006 Caesar Lack: Forecasting Swiss inflation using VAR models

01/2005 Mathias Zurlinden: Credit in the monetary transmission mechanism: An overview of some recent research using Swiss data

As of issue $8 / 2014$, the publication series is called SNB Economic Studies (previously: Swiss National Bank Economic Studies).

All SNB Economic Studies are available for download at: www.snb.ch, Research

Subscriptions or individual issues can be ordered at: Swiss National Bank

Library

P.O. Box

$\mathrm{CH}-8022$ Zurich

Phone: +41 446313284

Fax: +41446318114

E-mail: library@snb.ch 
SCHWEIZERISCHE NATIONALBANK

BANQUE NATIONALE SUISSE

BANCA NAZIONALE SVIZZERA

BANCA NAZIUNALA SVIZRA

SWISS NATIONAL BANK 